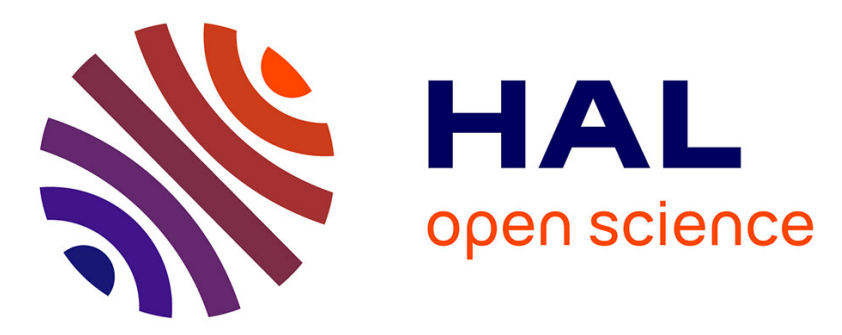

\title{
Formation and Persistence of Extensional Internally Drained Basins: The Case of the Fucino Basin (Central Apennines, Italy)
}

Riccardo Lanari, C. Faccenna, Lucilla Benedetti, A. Sembroni, Olivier Bellier, I. Menichelli, P. Primerano, P. Molin

\section{- To cite this version:}

Riccardo Lanari, C. Faccenna, Lucilla Benedetti, A. Sembroni, Olivier Bellier, et al.. Formation and Persistence of Extensional Internally Drained Basins: The Case of the Fucino Basin (Central Apennines, Italy). Tectonics, 2021, 40 (6), 10.1029/2020TC006442 . hal-03453661

\section{HAL Id: hal-03453661 \\ https://hal.science/hal-03453661}

Submitted on 28 Nov 2021

HAL is a multi-disciplinary open access archive for the deposit and dissemination of scientific research documents, whether they are published or not. The documents may come from teaching and research institutions in France or abroad, or from public or private research centers.
L'archive ouverte pluridisciplinaire HAL, est destinée au dépôt et à la diffusion de documents scientifiques de niveau recherche, publiés ou non, émanant des établissements d'enseignement et de recherche français ou étrangers, des laboratoires publics ou privés. 
1 Formation and persistence of extensional internally-drained basins: the case of the

2 Fucino basin (Central Apennines, Italy)

3

4 R. Lanari ${ }^{1,2}$, C. Faccenna ${ }^{1,3}$, L. Benedetti ${ }^{4}$, A. Sembroni ${ }^{1,5}$, O. Bellier ${ }^{4,6}$, I. Menichelli ${ }^{1}$, P.

$5 \quad$ Primerano $^{1}$ and P. Molin ${ }^{1}$.

$6{ }^{1}$ Department of Sciences, University of Roma Tre, Italy.

$7 \quad{ }^{2}$ Department of Earth Sciences, University of Florence, Italy

$8{ }^{3}$ Jackson School of Geoscience, University of Texas, Austin, TX USA.

$9{ }^{4}$ Aix Marseille Univ, CNRS, IRD, INRAE, Coll France, CEREGE, Aix-en-Provence, France.

$10{ }^{5}$ Department for the Cultural Heritage, University of Bologna, Italy.

$11{ }^{6}$ Aix Marseille Univ, CNRS, ECCOREV, Aix-en-Provence, France.

Corresponding author: Riccardo Lanari (riccardo.lanari@uniroma3.it)

Keywords

Fucino Basin, Slip-direction, Central Apennines, sedimentary load.

Highlights:

- Role of tectonics and drainage systems in the evolution of extensional basins

- Extensional fault network and sedimentary loading keep the Fucino Basin internally drained during its evolution.

- Sediment load contributes to incrementing of max $30 \%$ the faults total geological throw and locally reorganizes the stress field. 
Abstract

The interaction between sedimentation/erosion and faulting represents one of the most intriguing topics in landscape and tectonics evolution. Only few studies have been able to document the feedback between faulting and sedimentary loading from field observations. Here, we focus on how sediment loading/unloading influences the dynamics of fault systems in the Fucino Basin, in the Central Apennines (Italy). The Fucino Basin represents a remarkable case study with respect to the other main extensional basins in the Apennines, because of its large dimension, square shape, significant sediment thickness and, its endorheic nature throughout its evolution.

We present a detailed structural and geomorphologic analysis of the Fucino Basin and its surroundings, investigating the kinematic and geometry of each main fault strand. The slickenlines analysis reveals multiple families of slip-vectors and timing of activity, suggesting a change in extension slip-direction from $\mathrm{N} 240^{\circ}$ to $\mathrm{N} 200^{\circ}$ during middle Pleistocene. Using a local isostatic model, we estimate that up to the $30 \%$ of the vertical geological displacement of the faults, which overall ranges from 0.5 to $2.5 \mathrm{~km}$, is related to the sediment loading/unloading. We demonstrate a positive feedback between sedimentation and faulting which may also lead to a re-organization in fault kinematics related to a significant increase in vertical stress. We propose a conceptual model 48 for the permanent endorheic configuration of the Fucino Basin, which includes the effect of sediment loading.

50 


\section{Introduction}

Extension of the crust generates normal faults and basins where sediments are trapped. Morphologically, extensional basins are generally classified as internally (endorheic) or externally (exorheic) drained. In the case of an internally drained basin, sediments are transported and stored within it. If the basin is externally drained, sediments are transported out of the basin and deposited in distal regions. The internally drained stage of extensional basins is generally a transient feature as these basins often evolve into an externally drained basin. Endorheic-exorheic and exorheic-endorheic transitions have been documented in several rifts basins, in compressional and extensional settings, to unravel the feedback between sedimentation-erosion-climate and tectonics (e.g. Berry et al., 2019; Bialas and Buck, 2009; Bucher et al., 2021; Garcia-Castellanos, 2007; Garcia-Castellanos et al., 2003; Geurts et al., 2018; Nichols, 2004; Sobel et al., 2003; Strecker et al., 2007). Numerical models of landscape evolution describe the role of strain rate in extensional basin systems, such as Rio Grande and East African rifts (Berry et al., 2019).

Drainage systems and sedimentary budgets of basins impact their fault systems. In fact, the sedimentary budget may influence the fault patterns (e.g. Ballato et al., 2019; Maniatis et al., 2009; Olive et al., 2014; Steer et al., 2014; Turpeinen et al., 2008; Vernant et al., 2013; Whipple, 2009). Local unloading may influence fault slip, and even trigger seismicity (e.g. Calais et al., 2010; Hampel et al., 2009, 2007; Hampel and Hetzel, 2006; Hetzel and Hampel, 2005; Mey et al., 2016). The feedback between faulting and sedimentary loading may thus be particularly relevant for internally drained basins, where the sediments are expected to be more abundant.

In this paper, we investigate the relation between faulting and sedimentation, focusing on the Fucino Basin in the Central Apennines (Italy, Fig. 1). Here, normal faulting and erosion processes shaped the landscape, producing a basin-and-range-type mountain belt forming both endorheic and exorheic basins. The main tectonic basins are Rieti, Leonessa, L'Aquila, Sulmona, Fucino and Subequana Valley (Fig. 1a). Some of these basins are externally drained by the Aterno-Pescara, the Sangro, the Salto-Tevere and the Liri rivers. Other basins are internally drained such as the Fucino, the Campo Felice, the Piani di Pezza and the Altopiano delle Rocche basins (Fig. 1b). Despite the fact that all these basins evolved at the same time and under the same tectonic regime (e.g. Cosentino et al., 2017), they show remarkable differences in terms of dimensions and sediments thickness. We focus in this study on the Fucino Basin, because of: (1) its large dimensions ( 200 $\mathrm{km}^{2}$ ); (2) an almost square shape due to the presence of two orthogonal faults (Fig.1) rather than an elongated shape (e.g. Sulmona or L'Aquila Basin; Fig.1); (3) sediment thickness which reaches 
almost $1 \mathrm{~km}$ (Cavinato et al., 2002) compared to 350 m (e.g. Sumona Basin, Subequana Valley, L'Aquila; Gori et al., 2017; Nocentini et al., 2018, 2017), and 600 m (eastern L'Aquila basin; Nocentini et al., 2018). The Fucino Basin has remained endorheic whereas the other intermontane basins underwent through endorheic-exorheic transitions and vice versa (e.g. D'Agostino et al., 2001b; Geurts et al., 2019, 2018).

The aim is to understand the conditions that allowed the Fucino Basin to preserve its internal drainage during its entire evolution. We perform a detailed structural analysis to define the geometry and the kinematic evolution of the main faults around the Fucino Basin. We also provide a geomorphological analysis including swath profiles, steepness index, local relief and slope maps, and drainage divide stability analysis (Forte and Whipple, 2018) to investigate the linkage between erosion and faulting. Our results reveal that sedimentary processes increase the fault offsets around the Fucino area up to $30 \%$, mainly due to both hanging wall loading and footwall unloading. We interpret the observed change in strain direction as an increase of the vertical stress due to the sedimentary loading. We speculate that the coexistence of two orthogonal faults (which is the major difference between the Fucino Basin and any other intermontane depression in the Central Apennines) combined with the sediment (un)loading is responsible for enhancing the subsidence and the stress reorganization. This prevents the Fucino Basin to be captured by nearby rivers, favoring the long-lasting endorheic state of the basin.

\section{Geological Setting}

\subsection{Structural setting, kinematic and throw distribution along the Central Apennines}

The Apennine mountain belt is an asymmetric Neogene fold-and-thrust accretionary wedge produced by the subduction of the Adria Plate (Cipollari and Cosentino, 1996; Cosentino et al., 2010; Merlini and Mostardini, 1986; Patacca et al., 1992). Crustal accretion is progressively younger eastward toward the foreland and is followed by extensional deformation. Extensional deformation produced a set of normal faults striking sub-parallel to the older thrusts and trending mainly NW-SE. The most active normal fault system is located on the top of the wedge and it is responsible for the formation of intermontane basins. The only exception to this pattern is the Avezzano-Buzzi fault system which strikes instead NE-SW from the Fucino to the Sulmona basin (Fig. 1a; Gori et al., 2017).

Several studies documented and explored the geometry and kinematics of the normal faults, which are particularly well exposed on the carbonate deposits of the Central Apennines (Cowie et 
al., 2017; Cowie and Roberts, 2001; Faure Walker et al., 2012, 2010, 2009; Galadini, 1999; Galadini et al., 1997; Galadini and Galli, 2000; Gori et al., 2017; Papanikolaou et al., 2005; Piccardi et al., 1999; Pizzi and Pugliese, 2004; Roberts et al., 2004; Roberts and Michetti, 2004; Salvi et al., 2003; Smeraglia et al., 2016; Wilkinson et al., 2015); investigating also the role of tectonics in landscape evolution of the Central Apennines (e.g. Bubeck et al., 2015; Geurts et al., 2019, 2018; Whittaker et al., 2007). Structural analysis of the faults shows a prevalent NNE-SSW to ENE-WSW direction of extension (Faure Walker et al., 2010), with a mean direction oriented NE-SW. This is consistent with focal mechanisms, borehole breakout data, inversion of micro-earthquakes and geodetic strain (Fig. 1a; D’Agostino et al., 2001a; Montone et al., 2012, 1999). In several locations surrounding the Fucino basin, multiple direction of slickenlines have been measured and: (1) averaged and interpreted as due to fault growth and linkage (e.g. Roberts and Michetti, 2004), (2) associated to block rotation (Piccardi et al., 1999) or in general to a previous tectonic deformation (Galadini, 1999). The geological throw of those normal faults ranges from 500 to $2500 \mathrm{~m}$ and is larger on the Sulmona, L'Aquila and Rieti faults (Morewood and Roberts, 2000; Roberts and Michetti, 2004). A maximum cumulative throw of $6600 \pm 800 \mathrm{~m}$ has been estimated along a section crossing the Fucino and the Sulmona basins (Roberts and Michetti, 2004).

\subsection{Structural setting of the Fucino Basin}

The Fucino Basin is one of the largest extensional basins in the Central Apennines and is at an elevation of $600 \mathrm{~m}$ a.s.I. It is bordered to the east by the San Benedetto, Pescina and Collarmele faults, which extend southward and northward to become the Gioia de Marsi and the OvindoliCelano faults, respectively; by the Vallelonga fault on the western side (Fig. 2) and bordered to the north by the Tremonti and Velino-Magnola faults. These two sets of orthogonal normal faults give the Fucino Basin an almost square shape. Other extensional basins are more elongated and controlled by only one faults strand (Fig.1a). The existence of the two sets of orthogonal faults as well for the age of the Avezzano-Buzzi faults is unclear (Tremonti and Celano-Aielli; Fig. 1). It has been suggested that the Avezzano-Buzzi fault was active during the Apennines compressional phase as a lateral ramp and then has been reactivated during the Plio-Quaternary extension (e.g. Gori et al., 2017). Further north, two other main faults are present: the Piani di Pezza and Campo Felice (Figs. 2 and 3).

The Fucino Basin is surrounded by four major exorheic catchments: the Salto-Tevere and Liri basins to the west and the Sangro and the Aterno-Pescara basins to the east (Fig. 1b). On its 
northern side, the Fucino Basin is delimited by small endorheic catchments, such as the Campo Felice, the Piani di Pezza and the Altopiano delle Rocche basins (Fig. 1b).

Paleoseismological trenching across these structures show evidence of several large earthquakes in the last 7 ky affecting the Piani di Pezza-Ovindoli, Gioia de Marsi and Vallelonga faults with a slip from submeter to meters (D'Addezio et al., 1996; Galadini and Galli, 1999; Michetti et al., 1996; Pantosti et al., 1996; Salvi et al., 2003). Slip rate deduced by ${ }^{36} \mathrm{Cl}$ cosmogenic dating along the faults escarpments ranges from 0.2 to $1.2 \mathrm{~mm} / \mathrm{yr}$ (Benedetti et al., 2013; Palumbo et al., 2004; Schlagenhauf et al., 2011). Cosmogenic analysis and paleoseismological trenching attest an increase of Holocene slip around the Fucino Basin (Benedetti et al., 2013).

Interpretation of seismic lines and borehole stratigraphy data provide depth, geometry, and maximum sediment thickness of the Fucino Basin (Cavinato et al., 2002). The sedimentary infill is up to 950 meters thick, and consists of lacustrine, alluvial and fluvial sediments deposited from late Pliocene onward (Cavinato et al., 2002; Mondati et al., 2021). Two sedimentary sequences (sequence 3 and 4, Fig. 2; Cavinato et al., 2002), separated by an unconformity, indicate the occurrence of main extensional or climate events during the late Pliocene and since middle Pleistocene (Cavinato et al., 2002). The Piani di Pezza and Campo Felice faults are younger than the Fucino faults, and have been active since the middle Pleistocene (Giraudi, 2012; Giraudi et al., 2011; Villani et al., 2015).

\section{Methods}

\subsection{Structural analysis}

We carried out a structural analysis around the Fucino Basin and measured the strike and dip of the main faults and the pitch angle or the azimuth of the slickenlines. The sense of shear of these structures has been deduced by kinematic indicators such as Riedel shear and lunate structures. In case of multiple slickenlines, cross cutting relationships provide the relative chronology. We plotted the analyze data using the 'Daisy' software (Salvini, 2004). Figure 3 shows the transport direction of the hanging wall with respect to the footwall of each measurement site and the cumulative along each fault (stereoplot; Fig. 3). Field observations and frequency analysis of the azimuth of the slip-directions were performed to distinguish between different slickenside populations. In supporting information (Figs. S3, S4 and S5), we show data and gaussian distribution of the slip directions for each fault strand. This analysis, together with the cross- 
191 cutting observations, is essential to distinguish between a dispersion of data collection along a 192 mean direction and/or two distinct clusters.

193 Serial cross sections provide the throws along faults using geological markers and corrected for the 194 apparent angle if sections were not orthogonal to the fault strands (Figs. S3, S4 and S5 supporting 195 information). Since multiple fault slip-directions are present, the fault throw cannot be estimated 196 easily, thus we estimate the vertical component of the fault throw.

\subsection{Morphometric quantitative analysis}

199 We perform a morphometric quantitative analysis, including swath profiles, maps of local relief 200 and slope, river network analysis $\left(k_{s n}\right)$, and drainage divide stability analysis to investigate the 201 landscape and the drainage area of the Fucino Basin. All these analyses have been realized by 202 using SRTM DEM raw topographic data $(\sim 90 \mathrm{~m}$ in horizontal resolution) 203 (http://srtm.csi.cgiar.org/srtmdata/) in GIS environments and MatLab. Two swath profiles, 204 respectively NW-SE and SW-NE trending, are extracted from SRTM DEM data by using 205 TopoToolBox (Schwanghart and Kuhn, 2010). The elevation along each profile is sampled each 100 $206 \mathrm{~m}$ into an observation window $5 \mathrm{~km}$ wide. The final plot represents the patterns of maximum, 207 minimum and mean topography (Isacks, 1992).

208 We perform a divide stability analysis around the Fucino Basin following Forte and Whipple (2018). 209 This analysis provides a snapshot of a possible watershed migration by a comparison of four 210 metrics across divide: gradient, local relief, $\chi$ (a proxy of steady-state channel elevation; see Willet 211 et al., 2014), and elevation. We do not discuss the $\chi$ outcome since it is strongly influenced by the 212 choice of the outlet elevation (Whipple et al., 2017) and in this respect, the Fucino base level 213 elevation is too different from any other reasonably chosen outlet for the external rivers (e.g. sea 214 level, change from bedrock to alluvial channel). In the analysis we use $10^{4} \mathrm{~m}^{2}$ as reference area 215 and $1000 \mathrm{~m}$ as radius of the local relief. We chose 10 segments along the main drainage divide 216 from different location in the Fucino Basin. Using a free MatLab tool 217 (http://github.com/amforte/DivideTools; Forte and Whipple, 2018), we plotted the relative results 218 in a single graph (Fig. 8b) where the error bar is the standard deviation derived from the 219 histograms included in the supporting information (Fig. S17). This plot provides informations of 220 the stability or of the direction of migration of each divide segment (Fig. 8b).

221 The slope and the local relief maps are created in a GIS environment. The latter represents the result of the subtraction of maximum and minimum topography elevation within a circular moving 
223 window of $5 \mathrm{~km}$ in radius. This proxy allows in the first order to identify (assuming the same 224 lithology, as for the case for this region) incised sectors, and in comparison with faults, their 225 bearing with tectonic.

226 The map of the normalized along-channel variation in steepness index $\left(k_{s n}\right)$ has been elaborated by 227 TopotoolBox (Schwanghart and Kuhn, 2010). $K_{s}$ is a morphometric parameter which, together with 228 the concavity index $(\vartheta)$, describes the shape of a river longitudinal profiles providing information 229 about the state of equilibrium of the drainage systems (Duvall et al., 2003; Kirby et al., 2003; Kirby 230 and Whipple, 2012; Snyder et al., 2000; Zaprowski et al., 2005). Usually, to compare river profiles 231 irrespective of basin drainage area, the $k_{s}$ is normalized $\left(k_{s n}\right)$ by using a reference concavity index 232 value in a range from 0.3 to 0.8 . The map of the along-channel variation in steepness index shows 233 (Fig. 8e) the changes in channel slope allowing an easy identification of knickpoints and their 234 possible correspondence with tectonic structures or rock type changes.

235 Although these analyses are strongly affected by the erodibility of the rock types, the study area 236 (Fig. 2) is composed mainly by one lithology: the Meso-Cenozoic limestone (Fig. 2). Thus, in the 237 study area, any variation in incision rates can be associated to climate or tectonic events rather 238 than lithological variations.

\section{Results}

\subsection{Structural data}

The Fucino Basin has a square shape, controlled mainly by Pescina-San Benedetto-Collarmele set of faults trending NW-SE to the east, and the Tremonti and Velino-Magnola faults trending WSWENE and NW-SE, to the north (Figs. 2 and 3). We integrated our structural data and geological displacements (long-term displacement; see Puliti et al. (2020) for details) for each fault strand are compiled with data from previous studies concerning the escarpments height (coseismic rupture providing the short-term displacement; see Puliti et al. (2020) for details), the morphologic displacements (morphologic evidence of faulting such as triangular facets providing the mid-term displacement; see Puliti et al. (2020) for details), the age of the sediments and the slip-rate from cosmogenic dating and paleoseismological trenching.

252 Fig. S1).

253 - The Campo Felice fault (CF) borders the endorheic basin to the NE. The fault strikes for $\sim 12 \mathrm{~km}$ with an average direction of $\mathrm{N} 125^{\circ}$ (Figs. 2 and 3). We measured two senses of motions: one 
oriented ${\mathrm{N} 202^{\circ}}^{\circ}$ and one, measured only at the eastern tip of the fault, oriented $\mathrm{N} 263^{\circ}$ (Table S1 and Fig. S3; supporting information). Using the Cretaceous bauxite levels as marker we estimated a maximum vertical geological offset of $\sim 1500 \mathrm{~m}$ (Fig. S3 supporting information). The maximum morphologic displacement along the CF fault is $230 \mathrm{~m}$ (Benedetti et al., 2013), the height of the most recent escarpment is $\sim 10 \mathrm{~m}$ (Wilkinson et al., 2015) and the Holocene slip rate is $\sim 1 \mathrm{~mm} / \mathrm{y}$ (Benedetti et al., 2013). Although the onset of the CF is unconstrained, the oldest deposits within the basin are middle Pleistocene in age (Giraudi, 2012; Giraudi et al., 2011).

- The Ovindoli-Celano fault (O) strikes for $\sim 12 \mathrm{~km}$ with a N-S orientation controlled at depth by the Ovindoli-Monti D'Ocre thrust front (De Vittorio and Faccenna, 1987). The structural analysis shows two senses of motion oriented $\mathrm{N} 230^{\circ}$ and $\mathrm{N} 183^{\circ}$ but no crosscutting relationship have been observed (Fig. 3 and Fig. S4 within supporting information).

- The Piani di Pezza fault (PP) represents the northern prosecution of the Ovindoli-Celano fault and borders the endorheic basin to the NE (Figs. 2 and 3). The fault strikes for $\sim 5 \mathrm{~km}$ and it is oriented from WNW-ESE in the western region, to NW-SE in the eastern region. Two sets of striations (PP2 in Figs. 2 and 4C) with clear cross cutting relationship indicate two directions of slip oriented N224 (older event) and oriented N167 (younger event) (Table S1 and Fig. S3; Supporting information). We estimated a maximum vertical geological offset of $\sim 1800 \mathrm{~m}$ (Fig. S3 Supporting information). The height of the most recent escarpment is $\sim 5.7 \mathrm{~m}$ (Villani et al., 2015). Trench exploration gives a Holocene slip rate ranging between 0.6 to $2.3 \mathrm{~mm} / \mathrm{y}$ (Pantosti et al., 1996). Base on the oldest deposit within the basin the onset of the PP fault is middle-late Pleistocene (Cinti et al., 1992; Giraudi and Frezzotti, 1997; Pantosti et al., 1996; Villani et al., 2015).

- The Velino fault (V) borders the SW flank of the Velino Mountain (Fig. 2). It strikes for $\sim 14 \mathrm{~km}$ and it is oriented $\mathrm{N} 150^{\circ}$ (Fig. 3). The Velino fault structural analysis shows one set of striations oriented ${\mathrm{N} 200^{\circ}}$ (Fig. S2; Supporting information). We estimated a vertical geological offset of 1000 m (Fig. S3; Supporting information). The maximum morphological displacement along the Velino faults is $\sim 750 \mathrm{~m}$ (Schlagenhauf et al., 2011) while the average scarp height is $\sim 9.5 \mathrm{~m}$ (Benedetti et al., 2013). Even though the onset of extension for this structure is not well constrained, the Velino fault is considered active since the middle-late Pliocene (Cavinato et al., 2002).

- The Magnola fault is the eastern portion of the Velino fault and borders the southern flank of the Magnola Mountain striking WNW-ESE (Figs. 2 and 3). Slip-directions cluster around N199 (Table S1 and Fig. S4; supporting information). At the measurement site M2 (Figs. 3 and 5), two families 
of striations and cross cutting relationships indicate two directions: one recent oriented $\mathrm{N} 195^{\circ}$ and

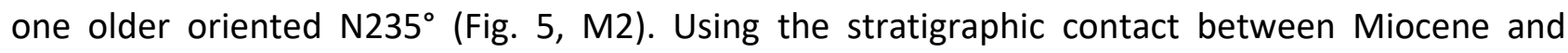
Cretaceous rocks we estimated a vertical geological offset of $\sim 2500 \mathrm{~m}$ (Fig. S4; supporting information). The morphologic displacement along the Magnola faults is up to $800 \mathrm{~m}$ (Schlagenhauf et al., 2011) while the escarpment height is up to $20 \mathrm{~m}$ with a slip rate of $\sim 1.3 \mathrm{~mm} / \mathrm{y}$ (Benedetti et al., 2013; Galli et al., 2012). The Magnola and Velino faults are consider active since the middle-late Pliocene (Cavinato et al., 2002), but the exact onset of extension is not constrained.

- The Tremonti fault borders the homonymous mountain, and it represents the direct north-west rim of the Fucino Basin (Figs. 2 and 3). It regionally strikes WSW-ENE. The slickenlines analysis shows multiple striations oriented $\mathrm{N} 210^{\circ}, \mathrm{N} 126^{\circ}$ and $\mathrm{N} 266^{\circ}$ (Table S1 and Fig. S4; supporting information). At site TRM4, we observed striations oriented $\mathrm{N} 183^{\circ}$ crosscutting the ones oriented $\mathrm{N} 261^{\circ}$ (Fig. 6). The vertical geological displacement is $\sim 1000 \mathrm{~m}$ (after Cavinato et al, 2002), morphologic displacement is $\sim 450 \mathrm{~m}$ and the escarpment height is $\sim 3.5 \mathrm{~m}$ with a slip rate of $\sim 0.2$ $\mathrm{mm} / \mathrm{y}$ (Benedetti et al., 2013). The onset of faulting is debated due to its possible activation during the Apennines orogenesis as a lateral ramp (Gori et al., 2017). Cavinato et al. (2002) proposed a late Pliocene onset of activation.

- The Celano-Aielli fault represents the eastern portion of the Tremonti fault, located east of the San Benedetto fault (Fig. 2). It strikes NE-SW, and we measured three main senses of motion: one $\mathrm{N} 267^{\circ}$, one $\mathrm{N}^{209^{\circ}}$ and one N98 (Fig. 3 and S5 supporting information). The Celano-Aielli fault is considered to be active from middle-late Pliocene (Cavinato et al., 2002; Gori et al., 2017).

- The Aschi Alto (or San Sebastiano) fault represents the southern portion of the Pescina Fault (Fig. 2). It strikes NW-SE and show two sets of striations; $214^{\circ}$ and $\mathrm{N} 162^{\circ}$ (Table S1 and Fig. S5; supporting information). The vertical displacement is $\sim 500 \mathrm{~m}$ (Praturlon, 1968) (Fig. 2), the escarpment height is $\sim 4 \mathrm{~m}$, and the slip rate is $\sim 0.5 \mathrm{~mm} / \mathrm{y}$ (Benedetti et al., 2013). The Aschi Alto fault is active from middle-late Pleistocene (Cavinato et al., 2002; Gori et al., 2017).

- The Gioia Dei Marsi fault represents the southern portion of the San Benedetto fault (Figs. 2 and 3) and strikes $\mathrm{N} 120^{\circ}$. We measured two senses of motion with cross cutting relationships (Fig. 3 and 7). The older striation is oriented $\mathrm{N} 182^{\circ}$ while the younger striation is oriented $\mathrm{N} 225^{\circ}$ (Fig. 7,

317 (Praturlon, 1968) (Fig. 2). The Gioia Dei Marsi fault is considered active since middle-late Pliocene 318 (Cavinato et al., 2002; Gori et al., 2017). 
- The Vallelonga (or Trasacco) fault borders the valley located in the southern rim of the Fucino Basin (Figs. 2 and 3). It strikes $\sim 20 \mathrm{~km}$ with a NW-SE orientation. We measured two slip-directions and a cross cutting relationship: one younger oriented $\mathrm{N} 253^{\circ}$ and one older oriented $\mathrm{N} 171^{\circ}$ (Table S1 and Fig. S5; supporting information). The vertical geological displacement is $\sim 300 \mathrm{~m}$ (Praturlon, 1968), the maximum morphologic displacement is $\sim 250 \mathrm{~m}$ and the maximum escarpment height is $\sim 4.7 \mathrm{~m}$ with a slip rate of $\sim 0.2 \mathrm{~mm} / \mathrm{y}$ (Benedetti et al., 2013).

\subsection{Geomorphological and morphometric analysis}

The swath profile A-B (Fig. 8a) shows a marked difference in the general topographic setting between the northwestern (at the border between the Fucino and the Salto R. basin) and the southeastern side (at the border between the Fucino and the Sangro R. basins). The northwestern side shows a maximum topography lower $(<1000 \mathrm{~m})$ than the southeastern side $(\sim 2000 \mathrm{~m})$ and a minimum elevation only $\sim 50 \mathrm{~m}$ lower than the Fucino Basin one. To the $\mathrm{SE}$, the minimum topography is above $1000 \mathrm{~m}$ of elevation, with a peak, representative of the drainage divide, around $1300 \mathrm{~m}$.

The swath profile C-D runs orthogonal to the main tectonic structures of the area, highlighting the influence of tectonics on landscape (Fig. 8a). In general, the pattern of minimum, mean, and maximum elevation is similar. To the SW, the Liri R. valley interrupts the topography decreasing towards the Fucino Basin plain. Eastward, beyond the plain, the topography increases regularly up to $\sim 1500 \mathrm{~m}$ and then decreases towards the Aterno R. valley.

Our analysis of the drainage divide stability (Fig. 8b; and Fig. S10 Supporting information) suggest overall stability in the Fucino Basin. The maps of local relief, slope and $k_{s n}$ (Figs. $8 \mathrm{c}, \mathrm{d}$, e) show a similar pattern with the highest values (local relief of $1200-2100 \mathrm{~m}, k_{s n}$ of $80-500$ and slope $>30^{\circ}$ ) corresponding with the footwalls of normal faults and hanging walls of thrusts. The remainder of the area is characterized by medium-low values with the lowest ones (local relief and $k_{s n}$ ranges of 0-300 $\mathrm{m}$ and 0-20, respectively) associated with the bottom of main fluvial trunks (Figs. $8 \mathrm{c}, \mathrm{d}, \mathrm{s}$ ).

\section{Discussion}

\subsection{Synthesis of the structural data and comparison with previous studies}

Previous studies analyzed the structural setting of the region (Faure Walker et al., 2012, 2010, 2009; Galadini, 1999; Galadini et al., 1997; Galadini and Galli, 2000, 1999; Morewood and Roberts, 2000; Papanikolaou et al., 2005; Piccardi et al., 1999; Pizzi and Pugliese, 2004; Roberts and 
351 Michetti, 2004; Salvi et al., 2003; Smeraglia et al., 2016; Wilkinson et al., 2015). Our field 352 measurements, and the differences with previous studies are illustrated in the supporting 353 information. Nine figures and one table, synthesized field data measurements (Figs. S7 to S15 and 354 Table S2; Supporting information; Morewood and Roberts, 2000; Piccardi et al., 1999; Roberts and 355 Michetti, 2004; Smeraglia et al., 2016; Faure Walker et al., 2009; Wilkinson et al., 2015). 356 Measurements from this and previous studies are similar, in some case identical (Fig. S7 to S15; 357 Supporting information). Stereoplots from all previous works show the presence of multiple slip358 directions that have been interpreted: (1) as due to block rotation (as Piccardi et al., 1999), (2) 359 older tectonic phase (e.g. Galadini, 1999); or (3) have been averaged on a single direction 360 (Morewood and Roberts, 2000; Roberts and Michetti, 2004) to demonstrate variation of slip361 direction along-strike (Roberts and Michetti, 2004). In this work, the crosscutting relationship from 362 field observations (Figs. 4C, 5C, 6C and 7B), and frequency distribution of population of slip363 directions (rather than average), has been used as criteria to distinguish between one or two sets 364 of striations. At several sites, we define two distinct sets of slickensides (e.g. sites PP2, M2 and 365 TRM4), that we attribute to distinct episodes of transport directions along the faults. This 366 approach and result are in agreement with earlier study along the Tremonti fault (Galadini, 1999 367 and Piccardi et al., 1999; Smeraglia et al., 2016).

368 Our structural analysis reveals that the faults around the Fucino Basin show normal to transtensive 369 kinematics, and are oriented from NW-SE to NNW-SSE, with the only exception of the Tremonti370 Celano-Aielli fault (western tip of the Avezzano-Buzzi system; Fig. 1) which strikes NE-SW. Two 371 main slip-directions can be distinguished: $\mathrm{N} 230^{\circ}$ to $\mathrm{N} 260^{\circ}$ and $\mathrm{N} 200^{\circ}$ to $\mathrm{N} 220^{\circ}$. Few faults also 372 exhibit slip-direction of $\mathrm{N} 120^{\circ}$ to $\mathrm{N} 170^{\circ}$. In the northern region, slickenlines crosscutting 373 relationships indicate a coherent pattern of slip-direction change from $\mathrm{N} 240^{\circ}$ to $\mathrm{N} 200^{\circ}$ 374 (constrained with the M2, PP2 and TRM4 measurement sites, Figs. 4, 5, 6 and Fig. S6; supporting 375 information), in good agreement with previous works (e.g. Piccardi et al., 1999; Smeraglia et al., 376 2016). Conversely, in the southern regions, slip-directions change from $\mathrm{N} 170^{\circ}$ to $\mathrm{N} 220^{\circ}$ 377 (constrained with the GdM3 measurement site; Fig. 7 and Fig. S6 supporting information).

378 The vertical displacement on the faults increases, as expected, towards to the center of the Fucino 379 Basin. The southern faults, including the Vallelonga, Aschi Alto and Gioia de Marsi, show an offset 380 of $\sim 500 \mathrm{~m}$. The northern faults, including Campo Felice and Piani Di Pezza faults, have larger 381 offsets ranging between 1000 and $1800 \mathrm{~m}$, except for the Magnola fault, which displays an 382 exceptional vertical throw of $\sim 2500 \mathrm{~m}$. Offset has been estimated by direct field sections and 
updated 1:50,000 geological maps excluding for Vallelonga, Gioia dei Marsi and Aschi Alto where we used the updated "1:100.000 Foglio Geologico Sora N152" (Praturlon, 1968). Some of our estimates are in accord with previous ones (e.g. Magnola fault; Morewood and Roberts, 2000). Others instead differ from previous ones, as for the case of Vallelonga where we estimate $\sim 300 \mathrm{~m}$ (Praturlon, 1968) while others, in the same section, estimated up to $1400 \mathrm{~m}$ (Roberts and Michetti, 2004); or the case of Piani di Pezza fault where we estimate $\sim 1800 \mathrm{~m}$ of offset, while Roberts and Michetti (2004) estimated only 400 m (See Fig. S16 in the Supporting Information). The onset of extension in the study area is not contemporaneous on each fault strand. The Tremonti, San Benedetto and Magnola-Velino faults are the oldest structures (Cavinato et al., 2002; Gori et al., 2017), formed probably during the late Pliocene, while faults located on the southern and northern side of the basin formed since the early-middle Pleistocene (Cavinato et al., 2002; Cinti et al., 1992; Giraudi et al., 2011; Giraudi and Frezzotti, 1997; Villani et al., 2015).

\subsection{Morphometric observations and drainage divide position of the Fucino Basin}

The landscape of the area is characterized by deep valleys and steep ranges. The highest values of local relief, slope, and $k_{s n}$ correspond to both extensional and compressive structures, suggesting that tectonics influences the landscape. Evidence of this tectonic control is also shown by the current positions of the drainage divides that are mainly located on the topographic culminations related to thrusts anticline and normal faults, especially on the eastern-north/eastern and on the southwest sides (Fig. 8). Moreover, low values of local relief, slope, and ksn at in summit areas of mountains suggest that these sectors have not been yet reached by the erosion wave induced by the regional uplift likely started around 3 Ma (e.g. Cosentino et al., 2017, D’Agostino et al., 2001b; San Jose et al., 2020).

In the Central Apennines, D'Agostino et al. (2001b) proposed that although the Fucino Basin has been internally drained throughout its evolution, the original size has been reduced by the Salto River capturing (Figs. 1 and 8a). Here, the divide is located in an almost flat area (see slope and ksn in Fig. 8d and e) filled by late-Pliocene/early-Pleistocene lacustrine sediments (Centamore, 2004) and by the fluvio-glacial Majelama Valley fan (Frezzotti and Giraudi, 1992). The low energy lacustrine environment is inconsistent with the current base level of the Salto R. (Tyrrhenian Sea), suggesting a southeastward drainage divide migration. The Salto-Fucino divide represents the potential outlet for the Fucino Basin, but the $~ 30$ ka Majelama Fan emplacement (Fig. 2; Frezzotti and Giraudi, 1992) might have prevented the Salto river from capturing the Fucino Basin. 
415 The drainage divide stability analysis (Forte and Whipple, 2018; see also Fig. S17; supporting information) indicates an overall stability (as $\mathrm{N}^{\circ} 1-2-5-6-7$ and 8 , Fig. $8 \mathrm{~b}$ ) that is apparently

417 surprising as the Fucino is a large endorheic basin at $700 \mathrm{~m}$ of elevation. This stability could be interpreted as due to the activity of the faults that keeps the divide high in elevation and contrast the integration of the external rivers into the Fucino Basin. This is due to the fact that the faults deformation rates are higher than the incision rates of the external rivers, pinning the location of the drainage divide. The stability of the Fucino-Salto divide (divide 3; Fig.8b) is preserved by the low stream power of the Salto R. since its upstream portion has not been reached by the erosion related to the onset of the Quaternary regional uplift as evidenced by the very low values of channel steepness (Fig. 8e) and of the local relief (Fig. 8c). The Fucino-Sangro stable divide (divide 9 and 10; Fig. 8b) may represent a snapshot of a stability referred to previous boundary conditions. Indeed, the upstream Sangro R. valley is wide and hosts Lower Pleistocene fan deposits scarcely incised (Miccadei et al., 2012), suggesting limited erosion.

In summary, morphometric observations of the Fucino Basin indicate that tectonic deformation rates are faster than the erosion rates. This can be also inferred by the fact that the inactive (since middle Pliocene) compressional structures are still shaping the landscape and by the overall stable divides. We suggest that the Salto-Fucino divide migration occurred in recent time (likely since late-Pleistocene, Centamore, 2004), but it has been halted by the Valle Majelama fan (Frezzotti and Giraudi, 1992). Since this upstream portion of the Salto River has not been reached by the erosion relative to the regional uplift, the divides tend to have a very low rate of migration.

\subsection{Schematic evolution of the Fucino Basin and changes in the direction of extension}

Slip-directions, vertical offsets, Holocene slip rates and timing indicate an evolving pattern of deformation around the Fucino Basin that we can summarize in two main stages shown in Fig. 9. Stage 1 (Fig. 9a). The San Benedetto-Ovindoli, Tremonti and Velino-Magnola faults are the oldest structures, and likely formed during the late Pliocene (Cavinato et al., 2002), coeval with the onset of the Sulmona, L'Aquila and the Rieti basins (Cosentino et al., 2017). The kinematics of the Tremonti and Velino-Magnola faults were transtensive to dextral strike-slip (see also Cavinato et al., 2002), acting as transfer of the San Benedetto master fault. The coeval activity is well constrained by the oldest sedimentary sequence that is deposited at the junction between the San Benedetto and the Tremonti fault (Cavinato et al., 2002) (Fig. 9a). 
Stage 2 (Fig. 9b, c and d). The San Benedetto fault laterally propagates (northward and southward), reactivating older thrust faults, as the case of the Ovindoli-Celano structure (De Vittorio and Faccenna, 1987). During this time, the direction of extension rotated from $\mathrm{N} 240^{\circ}$ to $\mathrm{N} 200^{\circ}$ (Figure $9 \mathrm{~b}$ ). This new direction of extension ( $\mathrm{N} 200^{\circ}$ ) might have favored ruptures along new fault planes oriented even WNW-ESE, such as the Piani di Pezza or Campo Felice, rather than reactivating the deeper structures more oriented NNW-SSE, such as the Ovindoli or San Benedetto ones. Moreover, this new extensional field $\left(\mathrm{N} 200^{\circ}\right)$ favors reactivation with dip-slip kinematics of the Velino-Magnola and Tremonti structures which strike instead from WNW-ESE to NNW-SSE (Fig. 9b).

455 We suggest that the timing of the rotations in the slip-direction might have occurred around the middle Pleistocene before the formation of western Piani di Pezza (PP1 site of measurement) and Campo Felice faults that seem to present only the recent $\sim \mathrm{N} 200^{\circ}$ slip-direction (see station CF3 and CF1 from this study, and Morewood and Roberts, 2000; Wilkinson et al., 2015; Fig S7 supporting Information). This is also in good agreement with the age of a sedimentary hiatus between two sedimentary sequences within the Fucino Basin (Fig. 2), Pliocene-early Pleistocene and since middle-late Pleistocene in age, related to two separated extensional events (Cavinato et al., 2002).

\subsection{The Fucino Basin, the Central Apennines, and the role of the sediment loading}

The faults that border the Fucino Basin behave differently with respect to the Central Apennines geological context. In particular:

1) The most recent $\mathrm{N}_{200^{\circ}}$ direction of extension only occurs in the northern sector of the Fucino Basin. In fact, in the Central Apennines, slip-directions collected by previous studies, show a main extension, oriented NE-SW (Faure Walker et al., 2010). Moreover, stress maps derived from earthquakes and borehole breakouts indicate an overall direction for the minimum horizontal sigma ranging between ENE-WSW to NE-SW (Montone et al., 2012, 1999). This also agrees with a second invariant strain rate from geodesy showing a principal direction oriented NE-SW (Fig. 1a; D'Agostino et al., 2011). Similarly, in the southern Apennines, the current direction of extension is oriented NE-SW (Montone et al., 2012, 1999). This NE-SW direction of extension is also documented by previous slickenlines analysis (e.g. Papanikolaou and Roberts, 2007). For this region, the extensional direction over-imposed a previous one oriented NNWSSE developed since late Miocene (Hippolyte et al., 1994). 
2) The cumulative offsets across the faults located on the northern side of the Fucino Basin are larger than other faults in the Central Apennines. The vertical throw along the Velino-Magnola and Tremonti faults is $\sim 3.5 \mathrm{~km}$ which is higher than the vertical offsets of San BenedettoPescina/Collarmele faults or L'Aquila, Sulmona and Rieti faults, that all range between 1.0 and $2.5 \mathrm{~km}$ (Roberts and Michetti, 2004).

These differences between the Fucino and the Central Apennines faults in terms of direction of extension and cumulative vertical displacements could suggest that a local process is occurring at the scale of the Fucino Basin. In fact, comparison between independent data such as vertical geological displacement from this study, morphological displacement and the fault escarpments height from literature (Benedetti et al., 2013; Schlagenhauf et al., 2011; Villani et al., 2015; Wilkinson et al., 2015), indicates a remarkable increase of the values from north to south, i.e. towards the Fucino Basin (Fig. 10). The only exception to this pattern is the Velino vertical geological displacement which is lower than the northern faults. In this context, we note that only the Velino fault exhibits a gentle fault dip measured on the surface $\left(<45^{\circ}\right.$; see Table S1 and Fig. S3; supporting information). The overall pattern shown in Fig. 10 strongly accords with Holocene sliprates that also increases toward the basin, reaching maximum values along the Velino-Magnola fault (Benedetti et al., 2013). Hence, our and previous data indicate that the northern structures of the Fucino Basin are characterized by larger and faster displacement than the southern ones. We propose that sedimentary (un)loading plays an important role in the internal dynamics of the Fucino Basin, influencing the deformation pattern. On a first approximation, the sedimentary (un)loading over the faults may be estimated assuming local Airy isostasy (Fig. S18; Supporting information; England and Molnar, 1990). For the Fucino Basin, assuming a sediment thickness of $\sim 1 \mathrm{~km}$ (Cavinato et al., 2002) with density of $1700 \mathrm{~kg} / \mathrm{m}^{3}$, we estimate $\sim 400 \mathrm{~m}$ of subsidence of the San Benedetto hanging wall (Fig. 11 and Fig. S19; Supporting information). For the Magnola sector, assuming 1200 meters as a minimum estimation of thickness of the eroded material (Wise, 1985), we estimate maximum $1000 \mathrm{~m}$ of footwall uplift (Supporting information, Fig. S20). Assuming flexural isostasy (see details in supporting information) and using elastic thicknesses (Te) of 2, 4 and $6 \mathrm{~km}$ (cfr. with Te of $3.7 \mathrm{~km}$; D’Agostino and McKenzie, 1999) we generally obtain, as expected, lower values (see Figs. S21 and S22; Supporting information). For the hanging wall subsidence, we estimate $\sim 369(\mathrm{Te}=2 \mathrm{~km}), \sim 223(\mathrm{Te}=4 \mathrm{~km})$ and $\sim 165 \mathrm{~m}(\mathrm{Te}=6 \mathrm{~km})$ while for the footwall uplift $\sim 425(\mathrm{Te}=2 \mathrm{~km}), \sim 150(\mathrm{Te}=4 \mathrm{~km})$ and $\sim 81 \mathrm{~m}(\mathrm{Te}=6 \mathrm{~km})$. These isostatic vertical 
movements due to the (un)loading adjustment represent almost the $30 \%$ of the total geological vertical slip.

The sedimentary loading may also produce a local rotation of slip-direction, from $\mathrm{N} 240^{\circ}$ to $\mathrm{N} 200^{\circ}$. According to Anderson regime (Anderson, 1951), the increase in vertical stress due to sediment loading, which for the strike/oblique-slip is the intermediate stress ( $\sigma 2$; Anderson, 1951), may be enough to turn vertical stress into the principal one (Fig. 11b) ( $\sigma 1$; Anderson, 1951). This would result in a re-organization of the stresses. As discussed in section 4.3, we suggest that the change in the slip-direction, from $\mathrm{N} 240^{\circ}$ to $\mathrm{N} 200^{\circ}$, and in kinematics has occurred during middle Pleistocene, according to the hiatus related to an extensional phase and to the regional uplift between two sequences within the Fucino Basin (Cavinato et al., 2002). This implies that the older sequence 3 was related to an extensional event oriented $N 240^{\circ}$, while the younger sequence 4 was deposited during an extensional event oriented $\mathrm{N}^{2} 20^{\circ}$. Based on the thickness of the two sequences, we estimate that, since the onset of the deformation, the total vertical stress incremented by $\sim 15 \mathrm{MPa}$. According to this speculation, only $\sim 4 \mathrm{MPa}$ (estimated accounting only the thickness of sequence 4; Cavinato et al., 2002) were needed to turn the kinematic for strike/oblique- to dip-slip, as the case of the Tremonti fault (Fig. 11b).

\subsection{Feedback between tectonics, sediment loading and erosion}

The feedback between tectonics and sediment (un)loading might have a fundamental impact on the evolution of deformation. In extensional settings, hanging wall sedimentary load increases faults slip (Hampel et al., 2009, 2007; Turpeinen et al., 2008) by up to 15\% (Maniatis et al., 2009). This base level lowering as a result of fault slip increase, might increase the river slope profile and sediment production, resulting in an increased loading of the hanging wall. Conversely, in compressional settings, the sediment load over the hanging wall may delay thrust slip (Ballato et al., 2019; Hampel et al., 2009). Other studies reported that sediments or ice sheets (un)loading influence or even trigger seismicity (Hampel et al., 2009). Erosional unloading may gently flexure the upper crust, reducing the normal stress sufficiently to reactivate pre-existing structures, as occurred in the New Madrid seismic zone (United States) (Calais et al., 2010; Hampel et al., 2007; Hampel and Hetzel, 2006; Hetzel and Hampel, 2005; Steer et al., 2014; Vernant et al., 2013). In this context, the development of internally drained basins, and therefore the resultant storage of remarkable volumes of sediment, may exert a significant control on the kinematics of deformation, even at the scale of the orogens (e.g. Royden, 1996; Willett and Beaumont, 1994). 
541 Generally, endorheic-exorheic or exorheic-endorheic transitions are the result of a competition 542 between faulting, headward erosion and climate (e.g. Berry et al., 2019; D'Agostino et al., 2001b). 543 Although this is theoretically applicable in several geological contexts, it is important to 544 differentiate the formation of significantly large endorheic basins at the scale of mountain wedges 545 and the formation of small intermontane endorheic basins, as for example the case of the 546 Apennines. At the scale of an orogen, where significant crustal shortening is occurring, the 547 development of topographic barrier in the frontal range may limit the precipitation behind, 548 significantly reducing fluvial incision. This, in turn, may develop large internally drained basins, 549 such as on Puna-Altiplano Plateau, the Tibetan Plateau, and the Tarim basin (e.g. Sobel et al., 550 2003). The accumulation of kilometers of sediments at high-elevation basin forces the 551 deformation to shift toward the margins of the orogeny, significantly enlarging the wedge. In turn, 552 this produces a lowering in slope, relief and therefore fluvial incision, favoring the preservation 553 through time of the endorheic configuration (Royden, 1996; Willett, 1999; Willett and Beaumont, 554 1994).

555 At smaller scales, such as the Apennines, where the shadow effect of precipitation can be 556 neglected, endorheic-exorheic or exorheic-endorheic transitions are a common process mainly 557 due to the competition between faulting and fluvial headward erosion. If fluvial incision is faster 558 than footwall uplift along a fault, the rivers might cut across the fault, capturing a basin drainage 559 system (Fig. 12a). If the slip or footwall uplift rate become faster than the fluvial incision, the basin 560 becomes endorheic (Fig. 12a). The surface processes are affected by climate variations, that locally 561 might be the main controlling factor in decreasing in the fluvial incision. In our study area, this 562 process may have occurred in the Campo Felice or Piani di Pezza basins, where wind gaps 563 (Forcamiccia and Valico Di Pezza; Figs. 12 and 4A) suggest a previous exorheic configuration (Fig. 564 12a; Giraudi and Frezzotti, 1997; Giraudi et al., 2011). In any case, the small internally drainage 565 condition, especially for intermontane extensional basins, is not permanent and it is commonly 566 interrupted by a new capture from a nearby catchment.

567 If at the onset of deformation, the fault slip rate is faster than the erosion rate, the basin will be 568 endorheic (Fig. 12b). If the fluvial incision of adjacent basins becomes faster than the slip-rate, the 569 basin might be captured (Fig. 12b). A second scenario to explain the endorheic-exorheic transition 570 is the one associate to overspill processes (e.g. Geurts et al., 2019, 2018). This last model requires 571 that the amount of water and sediment load accumulated within the internally drained basin rises 572 to overflow the topographic barrier triggering the incision. In any case, in both scenarios 
573 (endorheic-exorheic transition due to headward erosion or overspill), this new externally drainage 574 configuration might be permanent since, once captured, the increased discharge makes the fluvial 575 incision rates much faster than vertical movement of the faults (D'Agostino et al., 2001b). In the 576 Central Apennines an example of endorheic-exorheic transition is the Sulmona basin, where the 577 Popoli Gorges cut through the Monte Morrone, linking the Sulmona basin with the Adriatic Sea 578 (D’Agostino et al., 2001b; Geurts et al., 2019; Fig. 1 and 12b). Interaction between erosion and faulting implies that during their evolution, the basins might be characterized by both endorheic and exorheic phases, making the permanent endorheic nature, as the case of the Fucino Basin, non-sustainable.

\subsection{Why is the endorheic nature of the Fucino Basin preserved?}

We propose a conceptual model that considers the original structural setting of the Fucino Basin. We attribute the endorheic nature of the Fucino Basin to the coeval presence of master (San Benedetto) and transfer faults (Tremonti and Velino-Magnola). We propose that the presence of these two orthogonal faults favors the endorheic drainage stage since the onset of extension (Fig. 13).

In our model for the preservation of the internally drained configuration since the onset of extension and through time the two following conditions are strongly tied to each other: (1) the sediment load and (2) the combination of the two orthogonal sets of faults.

1) Our work indicates that sediment-related vertical geological displacements only represent up to $30 \%$ of cumulative geologic throw across the San Benedetto-PescinaCollarmele and the Magnola faults. This non-extensional vertical displacement, in turn, increases the Fucino base level drop-down, enhancing erosion processes at higher elevation surface. At the same time, the enlarged accommodation space developed by faulting, allows to store more sediments overloading the faults hanging wall, inducing a self-sustaining positive feedback process.

2) The coexistence of two orthogonal faults (Tremonti-Celano Aielli Vs San BenettoCollarmele-Pescina) represents the main difference between the Fucino Basin and all the other extensional basins in the Central Apennines (Fig. 1). We suggest that this is the key for the preservation of the endorheic nature of the Fucino Basin through time. Our structural analysis shows a re-orientation along the transfer faults in the stress from $\mathrm{N} 240^{\circ}$

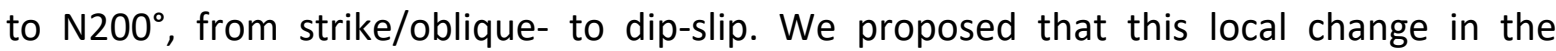


direction of extension and kinematic along the transfer faults might be related to the sediment loading. This increment of vertical stress may turn the vertical intermediate stress ( $\sigma 2$ ) into the principal stress ( $\sigma 1$; Anderson, 1951; Fig. 11). In turn, this kinematic changing along the original transfer faults favors the vertical displacement and subsidence on both master and transfer structures, self-triggering this process as described in point (1).

We suggest that the sediment-related additional vertical movement is one of the controlling factors for the permanent endorheic configuration of the Fucino Basin. It is worth to note that the Fucino Basin is located in a region that experiences both regional extension and uplift (San Jose et al., 2020). The uplift is fundamental to create, with the local footwall uplift, a topographic barrier against the nearby drainage basins.

In conclusion, we suggest that the competition between the sediment loading and the two orthogonal sets of faults that self-sustain each other with a positive feedback, could explain why the Fucino Basin remained endorheic through time. This increased subsidence prevents the basin to be captured by nearby catchments while the orthogonal set of structures that boarder the basin keeps the internal rivers to drain outside (Fig. 13).

\section{Conclusions}

We presented a detailed structural analysis of the Fucino Basin, estimating the vertical geological displacement of the main faults surrounding the region and the expected effects on vertical displacement using both local and flexural isostasy. We propose a conceptual model to explain the peculiar and permanent endorheic nature of the Fucino Basin.

The vertical geological offset of the main faults ranges from 500 to $2500 \mathrm{~m}$ increasing from north to south toward the Fucino Basin. Our estimates indicate that up to $30 \%$ of these geological offsets are due to sediment (un)loading. We also suggest that the consequent significant increase in vertical stress may lead to a re-organization of the kinematics, from oblique- to dip-slip, especially along the transfer faults such as Tremonti and Magnola faults. This change in the kinematics produces a local rotation in the main slip-direction from N240 ${ }^{\circ}$ to $\mathrm{N} 200^{\circ}$.

These findings allowed us to propose a conceptual model to better explain the endorheic nature of the Fucino Basin through time. We proposed that the combination of two orthogonal families of faults (San Benedetto and Tremonti) and the increasing slip, related to the sediment loading, prevents the Fucino Basin to be captured by nearby catchments. In turn, this process produces a 
positive feedback increasing the sediment overloading the hanging wall, which in turn increases the slip of the fault, preserving the internally drainage through time.

\section{Acknowledgement:}

We thank Fabio Corbi and Riccardo Reitano for the helpful discussions and Matteo Trolese and Alex Boutoux for field support. We also thank the Editor Laurent Jolivet and three anonymous reviewers for the constructive comments and criticisms. This work is supported by Dipartimento di Eccellenza grant (MIUR). Supporting information is available on 'https://osf.io/bd9a8/'.

\section{References}

Anderson, E.M., 1951. The dynamics of faulting.

Ballato, P., Brune, S., Strecker, M.R., 2019. Sedimentary loading - unloading cycles and faulting in intermontane basins : Insights from numerical modeling and field observations in the NW Argentine Andes. Earth Planet. Sci. Lett. 506, 388-396. https://doi.org/10.1016/j.epsl.2018.10.043

Benedetti, L., Manighetti, I., Gaudemer, Y., Finkel, R., Malavieille, J., Pou, K., Arnold, M., Aumaître, G., Bourles, D., Keddadouche, K., 2013. Earthquake synchrony and clustering on Fucino faults (Central Italy) as revealed from in situ 36Cl exposure dating. J. Geophys. Res. Solid Earth 118, 4948-4974.

Berry, M., Van Wijk, J., Cadol, D., Emry, E., Garcia-Castellanos, D., 2019. Endorheic-exorheic transitions of the Rio Grande and East African rifts. Geochemistry, Geophys. Geosystems.

Bialas, R.W., Buck, W.R., 2009. How sediment promotes narrow rifting: Application to the Gulf of California. Tectonics 28.

Bubeck, A., Wilkinson, M., Roberts, G.P., Cowie, P.A., McCaffrey, K.J.W., Phillips, R., Sammonds, P., 2015. The tectonic geomorphology of bedrock scarps on active normal faults in the Italian Apennines mapped using combined ground penetrating radar and terrestrial laser scanning. Geomorphology 237, 38-51.

Bucher, J., Paz, D.M., López, M., D’Elía, L., Bilmes, A., Varela, A., García, M., Feo, R., Fuentes, T., Franzese, J., 2021. Tectonic vs. climate controls on the evolution of a miocene intermontane basin, Patagonian Andean foreland, Argentina. Int. J. Earth Sci. 1-22.

Calais, E., Freed, A.M., Van Arsdale, R., Stein, S., 2010. Triggering of New Madrid seismicity by late-Pleistocene erosion. Nature 466, 608.

Cavinato, G.P., Carusi, C., Dall'Asta, M., Miccadei, E., Piacentini, T., 2002. Sedimentary and tectonic evolution of PlioPleistocene alluvial and lacustrine deposits of Fucino Basin (central Italy). Sediment. Geol. 148, $29-59$.

Centamore, E., 2004. Note Illustrative della carta geologica D'Italia alla scala 1:50.000. Foglio N. 368 “Avezzano." Serv. Geol. d'Italia.

Cinti, F.R., D’Addezio, G., Pantosti, D., Hamilton, J., 1992. Ricostruzione topografica di dettaglio della scarpata di faglia del Piano di Pezza, Abruzzo. 
Cosentino, D., Asti, R., Nocentini, M., Gliozzi, E., Kotsakis, T., Mattei, M., Esu, D., Spadi, M., Tallini, M., Cifelli, F., 2017. New insights into the onset and evolution of the central Apennine extensional intermontane basins based on the tectonically active L'Aquila Basin (central Italy). GSA Bull. 129, 1314-1336.

Cosentino, D., Cipollari, P., Marsili, P., Scrocca, D., 2010. Geology of the central Apennines: a regional review. J. virtual Explor. 36, 1-37.

Cowie, P.A., Phillips, R.J., Roberts, G.P., McCaffrey, K., Zijerveld, L.J.J., Gregory, L.C., Walker, J.F., Wedmore, L.N.J., Dunai, T.J., Binnie, S.A., 2017. Orogen-scale uplift in the central Italian Apennines drives episodic behaviour of earthquake faults. Sci. Rep. 7, 1-10.

Cowie, P.A., Roberts, G.P., 2001. Constraining slip rates and spacings for active normal faults. J. Struct. Geol. 23, 19011915.

D’Addezio, G., Pantosti, D., De Martini, P.M., 1996. Palaeoseismologic and geomorphic investigations along the middle portion of the Ovindoli-Pezza Fault (Central Italy). Ann. Geophys. 39.

D’Agostino, N., Giuliani, R., Mattone, M., Bonci, L., 2001a. Active crustal extension in the central Apennines (Italy) inferred from GPS measurements in the interval 1994-1999. Geophys. Res. Lett. 28, 2121-2124.

D’Agostino, N., Jackson, J.A., Dramis, F., Funiciello, R., 2001b. Interactions between mantle upwelling, drainage evolution and active normal faulting: an example from the central Apennines (Italy). Geophys. J. Int. 147, 475497.

D’Agostino, N., Mantenuto, S., D’Anastasio, E., Giuliani, R., Mattone, M., Calcaterra, S., Gambino, P., Bonci, L., 2011. Evidence for localized active extension in the central Apennines (Italy) from global positioning system observations. Geology 39, 291-294.

D’Agostino, N., McKenzie, D., 1999. Convective support of long-wavelength topography in the Apennines (Italy). Terra Nov.

De Vittorio, P., Faccenna, C., 1987. Ulteriori dati sulla tettonica da thrust presente nell'area Magnola-Sirente (Abruzzo Aquilano). Geol. Rom. 26, 287-291.

Duvall, A.R., BURBANK, D.W., KIRBY, E., 2003. Bedrock Channel Response to Variability in Rock Strenght and Rockuplift Rate in the Santa Ynez Mountains, California.

England, P., Molnar, P., 1990. Surface uplift, uplift of rocks, and exhumation of rocks. Geology 18, $1173-1177$.

Faure Walker, J.P., Roberts, G.P., Cowie, P.A., Papanikolaou, I., Michetti, A.M., Sammonds, P., Wilkinson, M., Mccaffrey, K.J.W., Phillips, R.J., 2012. Relationship between topography, rates of extension and mantle dynamics in the actively-extending Italian Apennines Adriatic Sea. Earth Planet. Sci. Lett. 325-326, 76-84. https://doi.org/10.1016/j.epsl.2012.01.028

Faure Walker, J.P., Roberts, G.P., Cowie, P.A., Papanikolaou, I.D., Sammonds, P.R., Michetti, A.M., Phillips, R.J., 2009. Horizontal strain-rates and throw-rates across breached relay zones, central Italy: Implications for the preservation of throw deficits at points of normal fault linkage. J. Struct. Geol. 31, 1145-1160.

Faure Walker, J.P., Roberts, G.P., Sammonds, P.R., Cowie, P., 2010. Comparison of earthquake strains over 102 and 104 year timescales: Insights into variability in the seismic cycle in the central Apennines, Italy. J. Geophys. Res. Solid Earth 115.

Forte, A.M., Whipple, K.X., 2018. Criteria and tools for determining drainage divide stability. Earth Planet. Sci. Lett. 493, 102-117. 
Frezzotti, M., Giraudi, C., 1992. Evoluzione geologica tardo-pleistocenica ed olocenica del conoide complesso di Valle Majelama (Massiccio del Velino, Abruzzo). Alp. Mediterr. Quat. 5, 33-50.

Galadini, F., 1999. Pleistocene changes in the central Apennine fault kinematics: a key to decipher active tectonics in central Italy. Tectonics 18, 877-894.

Galadini, F., Galli, P., 2000. Active tectonics in the central Apennines (Italy)-input data for seismic hazard assessment. Nat. Hazards 22, 225-268.

Galadini, F., Galli, P., 1999. The Holocene paleoearthquakes on the 1915 Avezzano earthquake faults (central Italy): implications for active tectonics in the central Apennines. Tectonophysics 308, 143-170.

Galadini, F., Galli, P., Giraudi, C., 1997. Geological investigations of Italian earthquakes: new paleoseismological data from the Fucino Plain (Central Italy). J. Geodyn. 24, 87-103.

Galli, P., Messina, P., Giaccio, B., Peronace, E., Quadrio, B., 2012. Early Pleistocene to late Holocene activity of the Magnola fault (Fucino fault system, central Italy). Boll. di Geofis. Teor. ed Appl. 53.

Garcia-Castellanos, D., 2007. The role of climate during high plateau formation. Insights from numerical experiments. Earth Planet. Sci. Lett. 257, 372-390.

Garcia-Castellanos, D., Vergés, J., Gaspar-Escribano, J., Cloetingh, S., 2003. Interplay between tectonics, climate, and fluvial transport during the Cenozoic evolution of the Ebro Basin (NE Iberia). J. Geophys. Res. Solid Earth 108.

Geurts, A.H., Cowie, P.A., Duclaux, G., Gawthorpe, R.L., Huismans, R.S., Pedersen, V.K., Wedmore, L.N.J., 2018. Drainage integration and sediment dispersal in active continental rifts: A numerical modelling study of the central Italian Apennines. Basin Res. 30, 965-989.

Geurts, A.H., Whittaker, A.C., Gawthorpe, R.L., Cowie, P.A., 2019. Transient landscape and stratigraphic responses to drainage integration in the actively extending central Italian Apennines. Geomorphology 107013.

Giraudi, C., 2012. The campo felice late pleistocene glaciation (apennines, central Italy). J. Quat. Sci. 27, 432-440.

Giraudi, C., Bodrato, G., Ricci, M., Cipriani, N., Villa, I.M., Giaccio, B., Zuppi, G.M., 2011. Middle and late Pleistocene glaciations in the Campo Felice Basin ( central Apennines, Italy ). Quat. Res. 75, 219-230. https://doi.org/10.1016/j.yqres.2010.06.006

Giraudi, C., Frezzotti, M., 1997. Late Pleistocene glacial events in the central Apennines, Italy. Quat. Res. 48, $280-290$. Gori, S., Falcucci, E., Ladina, C., Marzorati, S., Galadini, F., 2017. Active faulting, 3-D geological architecture and PlioQuaternary structural evolution of extensional basins in the central Apennine chain, Italy. Solid Earth.

Hampel, A., Hetzel, R., 2006. Response of normal faults to glacial-interglacial fluctuations of ice and water masses on Earth's surface. J. Geophys. Res. Solid Earth 111.

Hampel, A., Hetzel, R., Densmore, A.L., 2007. Postglacial slip-rate increase on the Teton normal fault, northern Basin and Range Province, caused by melting of the Yellowstone ice cap and deglaciation of the Teton Range? Geology 35, 1107-1110.

Hampel, A., Hetzel, R., Maniatis, G., Karow, T., 2009. Three-dimensional numerical modeling of slip rate variations on normal and thrust fault arrays during ice cap growth and melting. J. Geophys. Res. Solid Earth 114.

Hetzel, R., Hampel, A., 2005. Slip rate variations on normal faults during glacial-interglacial changes in surface loads. Nature 435, 81.

Hippolyte, J.-C., Angelier, J., Roure, F. (b), 1994. A major geodynamic change revealed by Quaternary stress patterns in the Southern Apennines (Italy). Tectonophysics 230, 199-210. 
Isacks, B.L., 1992. Long term land surface processes: erosion, tectonics and climate history in mountain belts. TERRA-1 Underst. Terr. Environ. Mather, P., Ed 21-36.

Kirby, E., Whipple, K.X., 2012. Expression of active tectonics in erosional landscapes. J. Struct. Geol. 44, 54-75. https://doi.org/10.1016/j.jsg.2012.07.009

Kirby, E., Whipple, K.X., Tang, W., Chen, Z., 2003. Distribution of active rock uplift along the eastern margin of the Tibetan Plateau: Inferences from bedrock channel longitudinal profiles. J. Geophys. Res. Solid Earth 108.

Maniatis, G., Kurfeß, D., Hampel, A., Heidbach, O., 2009. Slip acceleration on normal faults due to erosion and sedimentation-Results from a new three-dimensional numerical model coupling tectonics and landscape evolution. Earth Planet. Sci. Lett. 284, 570-582.

Merlini, S., Mostardini, F., 1986. Appennino Centro-Meridionale: sezioni geologiche e proposta di modello strutturale. Atti 73 Congr. Naz. Soc. Geol. It.(pre print) 147-150.

Mey, J., Scherler, D., Wickert, A.D., Egholm, D.L., Tesauro, M., Schildgen, T.F., Strecker, M.R., 2016. Glacial isostatic uplift of the European Alps. Nat. Commun. 7, 13382.

Miccadei, E., D’Alessandro, L., Parotto, M., Piacentini, T., Praturlon, A., 2012. Note illustrative alla Carta Geologica d’Italia (scala 1: 50.000), Foglio 378 “Scanno." Serv. Geol. d'Italia ISPRA.

Michetti, A.M., Brunamonte, F., Serva, L., Vittori, E., 1996. Trench investigations of the 1915 Fucino earthquake fault scarps (Abruzzo, Central Italy): geological evidence of large historical events. J. Geophys. Res. Solid Earth 101, 5921-5936.

Montone, P., Amato, A., Pondrelli, S., 1999. Active stress map of Italy. J. Geophys. Res. Solid Earth 104, $25595-25610$.

Montone, P., Mariucci, M.T., Pierdominici, S., 2012. The Italian present-day stress map. Geophys. J. Int. 189, 705-716.

Morewood, N.C., Roberts, G.P., 2000. The geometry, kinematics and rates of deformation within an en échelon normal fault segment boundary, central Italy. J. Struct. Geol. 22, 1027-1047.

Nichols, G.J., 2004. Sedimentation and base level in an endorheic basin: the early Miocene of the Ebro Basin, Spain. Boletín Geológico y Min. 115, 427-438.

Nocentini, M., Asti, R., Cosentino, D., Durante, F., Gliozzi, E., Macerola, L., Tallini, M., 2017. Plio-Quaternary geology of L'Aquila-Scoppito Basin (Central Italy). J. Maps 13, 563-574.

Nocentini, M., Cosentino, D., Spadi, M., Tallini, M., 2018. Plio-Quaternary geology of the Paganica-San DemetrioCastelnuovo Basin (Central Italy). J. Maps 14, 411-420.

Olive, J., Behn, M.D., Malatesta, L.C., 2014. Modes of extensional faulting controlled by surface processes. Geophys. Res. Lett. 41, 6725-6733.

Palumbo, L., Benedetti, L., Bourles, D., Cinque, A., Finkel, R., 2004. Slip history of the Magnola fault (Apennines, Central Italy) from $36 \mathrm{Cl}$ surface exposure dating: evidence for strong earthquakes over the Holocene. Earth Planet. Sci. Lett. 225, 163-176.

Pantosti, D., D’Addezio, G., Cinti, F.R., 1996. Paleoseismicity of the Ovindoli-Pezza fault, central Apennines, Italy: A history including a large, previously unrecorded earthquake in the Middle Ages (860-1300 AD). J. Geophys. Res. solid earth 101, 5937-5959.

Papanikolaou, I.D., Roberts, G.P., 2007. Geometry, kinematics and deformation rates along the active normal fault system in the southern Apennines: Implications for fault growth. J. Struct. Geol. 29, 166-188.

Papanikolaou, I.D., Roberts, G.P., Michetti, A.M., 2005. Fault scarps and deformation rates in Lazio-Abruzzo, Central 
Italy: Comparison between geological fault slip-rate and GPS data. Tectonophysics 408, 147-176.

Patacca, E., Scandone, P., Bellatalla, M., Perilli, N., Santini, U., 1992. The Numidian-sand event in the Southern Apennines. Mem. Sci. Geol. Padova 43, 297-337.

Piccardi, L., Gaudemer, Y., Tapponnier, P., Boccaletti, M., 1999. Active oblique extension in the central Apennines (Italy): evidence from the Fucino region. Geophys. J. Int. 139, 499-530.

Pizzi, A., Pugliese, G., 2004. InSAR-DEM analyses integrated with geologic field methods for the study of long-term seismogenic fault behavior: Applications in the axial zone of the central Apennines (Italy). J. Seismol. 8, 313-329.

Praturlon, A., 1968. Note Illustrative della Carta Geologica d'Italia alla scala 1: 100.000-Foglio 152 Sora. Serv. Geol. d'Italia.

Puliti, I., Pizzi, A., Benedetti, L., Di Domenica, A., Fleury, J., 2020. Comparing slip distribution of an active fault system at various timescales: Insights for the evolution of the Mt. Vettore-Mt. Bove fault system in Central Apennines. Tectonics 39, e2020TC006200.

Roberts, G.P., Cowie, P., Papanikolaou, I., Michetti, A.M., 2004. Fault scaling relationships, deformation rates and seismic hazards: an example from the Lazio-Abruzzo Apennines, central Italy. J. Struct. Geol. 26, 377-398.

Roberts, G.P., Michetti, A.M., 2004. Spatial and temporal variations in growth rates along active normal fault systems: an example from The Lazio-Abruzzo Apennines, central Italy. J. Struct. Geol. 26, 339-376.

Royden, L., 1996. Coupling and decoupling of crust and mantle in convergent orogens: Implications for strain partitioning in the crust. J. Geophys. Res. Solid Earth 101, 17679-17705.

Salvi, S., Cinti, F.R., Colini, L., D’addezio, G., Doumaz, F., Pettinelli, E., 2003. Investigation of the active Celano-L'Aquila fault system, Abruzzi (central Apennines, Italy) with combined ground-penetrating radar and palaeoseismic trenching. Geophys. J. Int. 155, 805-818.

Salvini, F., 2004. Structural data integrated system analyzer software (DAISY 3.0). Dip. di Sci. Geol. Univ. degli Stud. Roma Tre, Rome, Italy.

San Jose, M., Rugenstein, J.K.C., Cosentino, D., Faccenna, C., Fellin, M.G., Ghinassi, M., Martini, I., 2020. Stable isotope evidence for rapid uplift of the central Apennines since the late Pliocene. Earth Planet. Sci. Lett. 544, 116376.

Schlagenhauf, A., Manighetti, I., Benedetti, L., Gaudemer, Y., Finkel, R., Malavieille, J., Pou, K., 2011. Earthquake supercycles in Central Italy, inferred from Cl exposure dating L' Aquila. Earth Planet. Sci. Lett. https://doi.org/10.1016/j.epsl.2011.05.022

Schwanghart, W., Kuhn, N.J., 2010. TopoToolbox: A set of Matlab functions for topographic analysis. Environ. Model. Softw. 25, 770-781. https://doi.org/10.1016/j.envsoft.2009.12.002

Smeraglia, L., Berra, F., Billi, A., Boschi, C., Carminati, E., 2016. Origin and role of fluids involved in the seismic cycle of extensional faults in carbonate rocks Origin and role of fluids involved in the seismic cycle of extensional faults in carbonate rocks. Earth Planet. Sci. Lett. 450, 292-305. https://doi.org/10.1016/j.epsl.2016.06.042

Snyder, N.P., Whipple, K.X., Tucker, G.E., Merritts, D.J., 2000. Landscape response to tectonic forcing: Digital elevation model analysis of stream profiles in the Mendocino triple junction region, northern California. Geol. Soc. Am. Bull. 112, 1250-1263.

Sobel, E.R., Hilley, G.E., Strecker, M.R., 2003. Formation of internally drained contractional basins by aridity-limited bedrock incision. J. Geophys. Res. Solid Earth 108.

Steer, P., Simoes, M., Cattin, R., Shyu, J.B.H., 2014. Erosion influences the seismicity of active thrust faults. Nat. 
Strecker, M.R., Alonso, R.N., Bookhagen, B., Carrapa, B., Hilley, G.E., Sobel, E.R., Trauth, M.H., 2007. Tectonics and climate of the southern central Andes. Annu. Rev. Earth Planet. Sci. 35, 747-787.

Turpeinen, H., Hampel, A., Karow, T., Maniatis, G., 2008. Effect of ice sheet growth and melting on the slip evolution of thrust faults. Earth Planet. Sci. Lett. 269, 230-241.

Vernant, P., Hivert, F., Chery, J., Steer, P., Cattin, R., Rigo, A., 2013. Erosion-induced isostatic rebound triggers extension in low convergent mountain ranges. Geology 41, 467-470.

Villani, F., Tulliani, V., Sapia, V., Fierro, E., Civico, R., Pantosti, D., 2015. Shallow subsurface imaging of the Piano di Pezza active normal fault (central Italy) by high-resolution refraction and electrical resistivity tomography coupled with time-domain electromagnetic data. Geophys. Suppl. to Mon. Not. R. Astron. Soc. 203, 1482-1494.

Whipple, K.X., Forte, A.M., DiBiase, R.A., Gasparini, N.M., Ouimet, W.B., 2017. Timescales of landscape response to divide migration and drainage capture: Implications for the role of divide mobility in landscape evolution. J. Geophys. Res. Earth Surf. 122, 248-273.

Whittaker, A.C., Cowie, P.A., Attal, M., Tucker, G.E., Roberts, G.P., 2007. Contrasting transient and steady-state rivers crossing active normal faults: New field observations from the Central Apennines, Italy. Basin Res. 19, 529-556.

Wilkinson, M., Roberts, G.P., Mccaffrey, K., Cowie, P.A., Faure, J.P., Papanikolaou, I., Phillips, R.J., Michetti, A., Vittori,

\section{1} E., Gregory, L., Wedmore, L., Watson, Z.K., 2015. Geomorphology Slip distributions on active normal faults measured from LiDAR and fi eld mapping of geomorphic offsets : an example from L'Aquila, Italy, and implications for modelling seismic moment release. Geomorphology 237, 130-141. https://doi.org/10.1016/j.geomorph.2014.04.026

Willett, S.D., 1999. Orogeny and orography: The effects of erosion on the structure of mountain belts. J. Geophys. Res. Solid Earth 104, 28957-28981.

Willett, S.D., Beaumont, C., 1994. Subduction of Asian lithospheric mantle beneath Tibet inferred from models of continental collision. Nature 369, 642-645.

Wise, D. U., (1985). Restored structural contours of base of Miocene - Central Apennine, Italy.

Zaprowski, B.J., Pazzaglia, F.J., Evenson, E.B., 2005. Climatic influences on profile concavity and river incision. J. Geophys. Res. Earth Surf. 110.

\section{Figure Captions}

Figure 1: a) Topographic map of the Central Apennines with schematic traces of normal and thrust faults b) Topographic map of the Central Apennines with the river network and the main rivers.

Figure 2: Simplified geological map of the study area (see Fig. 1 for location) with in black the cross-section 
traces. At the bottom, schematic geological sections modified after Cavinato et al. (2002) and from 'Foglio Geologico Sora 152' (Praturlon, 1968).

Figure 3: Simplified structural map of the study area (see Fig. 1 for location) with the location of the measurement sites. The black arrows indicate the direction of movement of the hanging wall with respect to the footwall for each site. A merged stereoplot is shown for each fault with the hanging

Figure 4: A) Panoramic view of the Piani Di Pezza Fault. B and C) Detail of two slickenlines directions and cross cutting relationship on PP2 measurement site (Fig. 3). D) Stereoplot of the fault planes and slickenlines contour of PP2 measurement site. wall slip-direction (blue arrows).

Figure 5: A) Panoramic view of the Magnola Fault. B) Detail of the M2 measurement site (Fig. 3). C) Detail of two slickenlines directions and cross cutting relationship on M2 measurement site (Fig. 3). D) Stereoplot of the fault planes and slickenlines contour of M2 measurement site.

Figure 6: A) Panoramic view of the Tremonti Fault. B) Detail of the TRM4 measurement site (Fig.3). C) Detail of two slickenlines directions and cross cutting relationship on TRM4 measurement site (Fig. 3). D) Stereoplot of the fault planes and slickenlines contour of TRM4 measurement site.

Figure 8: a) Topographic map of the study area (left) and two swath profiles (right). The white boxes indicate the swath profile locations and the numbers the divide sections included in the divide stability analysis. b) Plot showing the results of the drainage divide stability analysis following Forte

Figure 9: Schematic evolutionary model from late Pliocene to Holocene, inspired by Cavinato et al. (2002). and Whipple (2018). c) Local relief map with $5 \mathrm{~km}$ of average circular window. d) Slope map. e) Map of the along channel variation of $k_{s n}$.

Figure 10: Simplified structural map of the study area (see Fig.1 for location) with the fault labeled based on a) escarpment height (short-term displacement; see Puliti et al. (2020) for detail) from previous studies (see main text for references), b) Morphological displacement (mid-term displacement; see 
Puliti et al. (2020) for detail) from previous studies (see main text for references) and c) geological throw (long-term displacement; see Puliti et al. (2020) for detail) from this work. In the lower plot displacements over faults.

906

Figure 11: The role of the sediments in the deformation. a) Sediments thickness from Cavinato et al. (2002) on the left and subsidence calculated using local isostasy model from Molnar and England, (1990). In the lower part topographic section: current topography, bedrock depth and expected bedrock depth without sediment loading. b) Kinematic changing and stress re-organization on the transfer fault (Tremonti Fault).

Figure 12: Conceptual model for endorheic-exorheic and exorheic-endorheic transition for small intermontane basins. a) Evolution from exorheic to endorheic with a panoramic view of Campo Felice basin. b) Evolution from endorheic to exorheic with a panoramic view of Sulmona basin.

Figure 13: Schematic and conceptual model for the endorheic preservation through time of the Fucino basin. 
Figure1. 

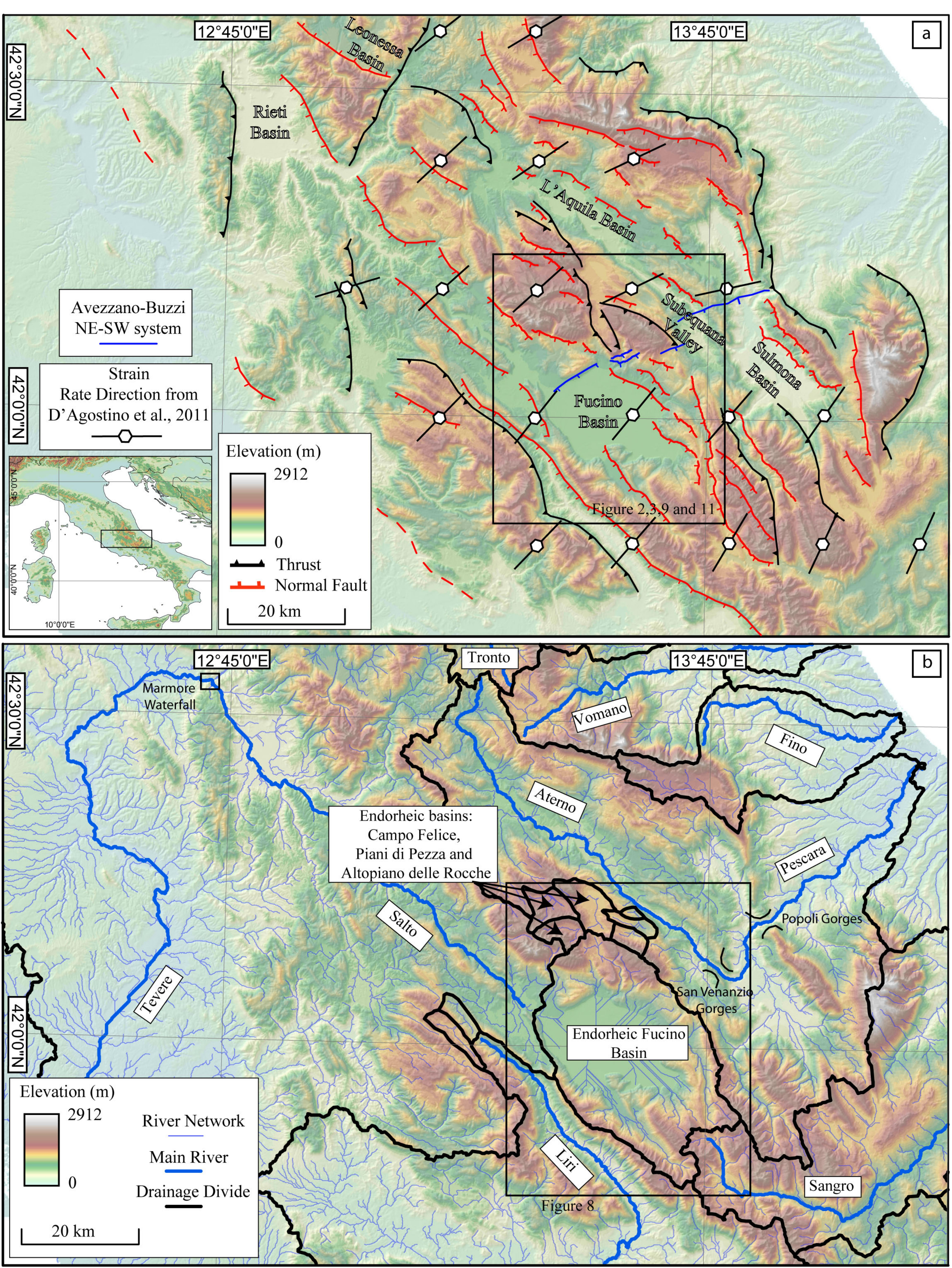
Figure2. 
Figure3. 
\begin{tabular}{l|l}
\cline { 2 - 2 } & (CF) Campo Felice Fault
\end{tabular} $\mathrm{N}$
(PP) Piani di Pezza Fault $\mathrm{N}$

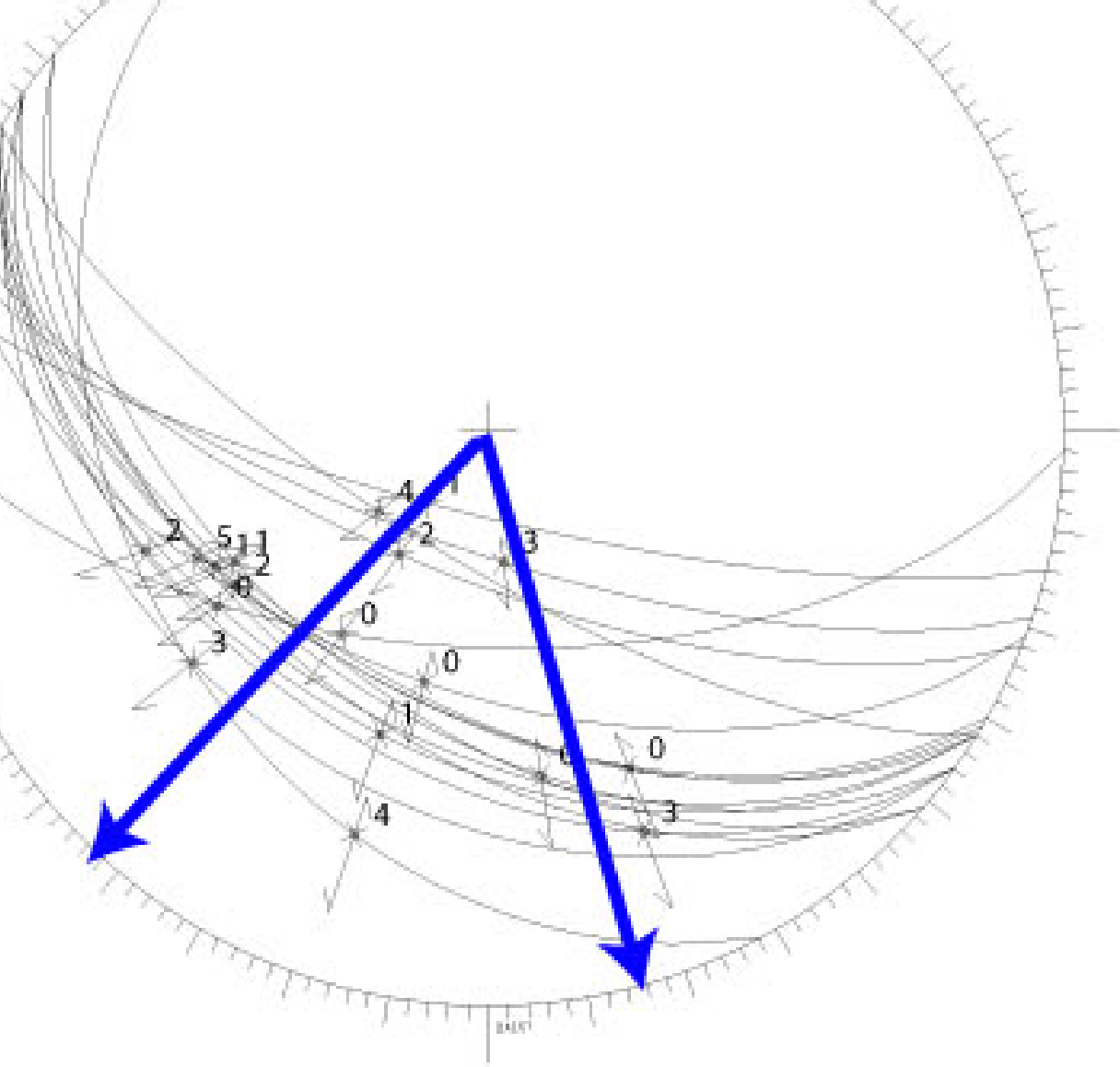

(V) Velino Fault $\mathrm{N}$
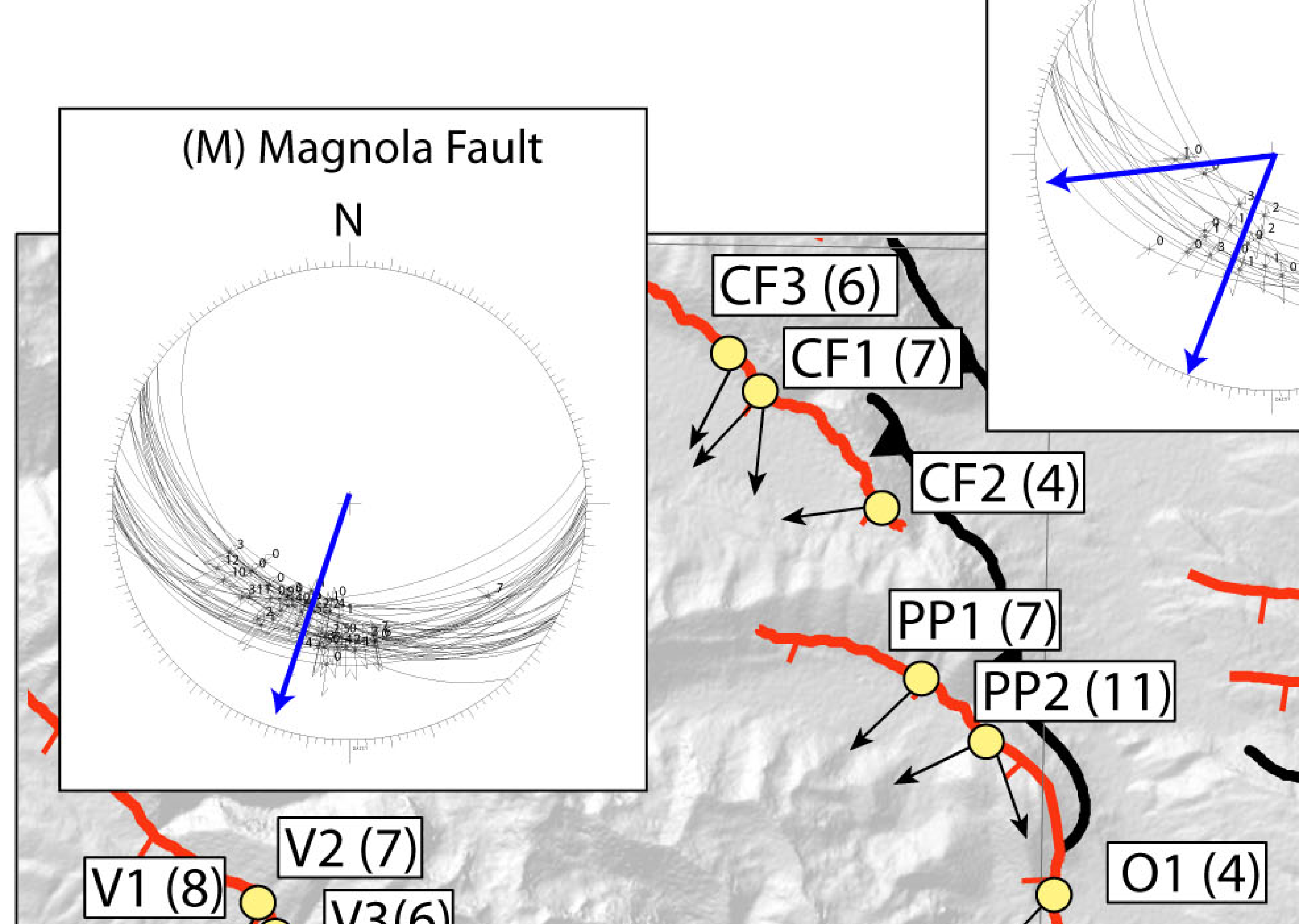

M2 (24)
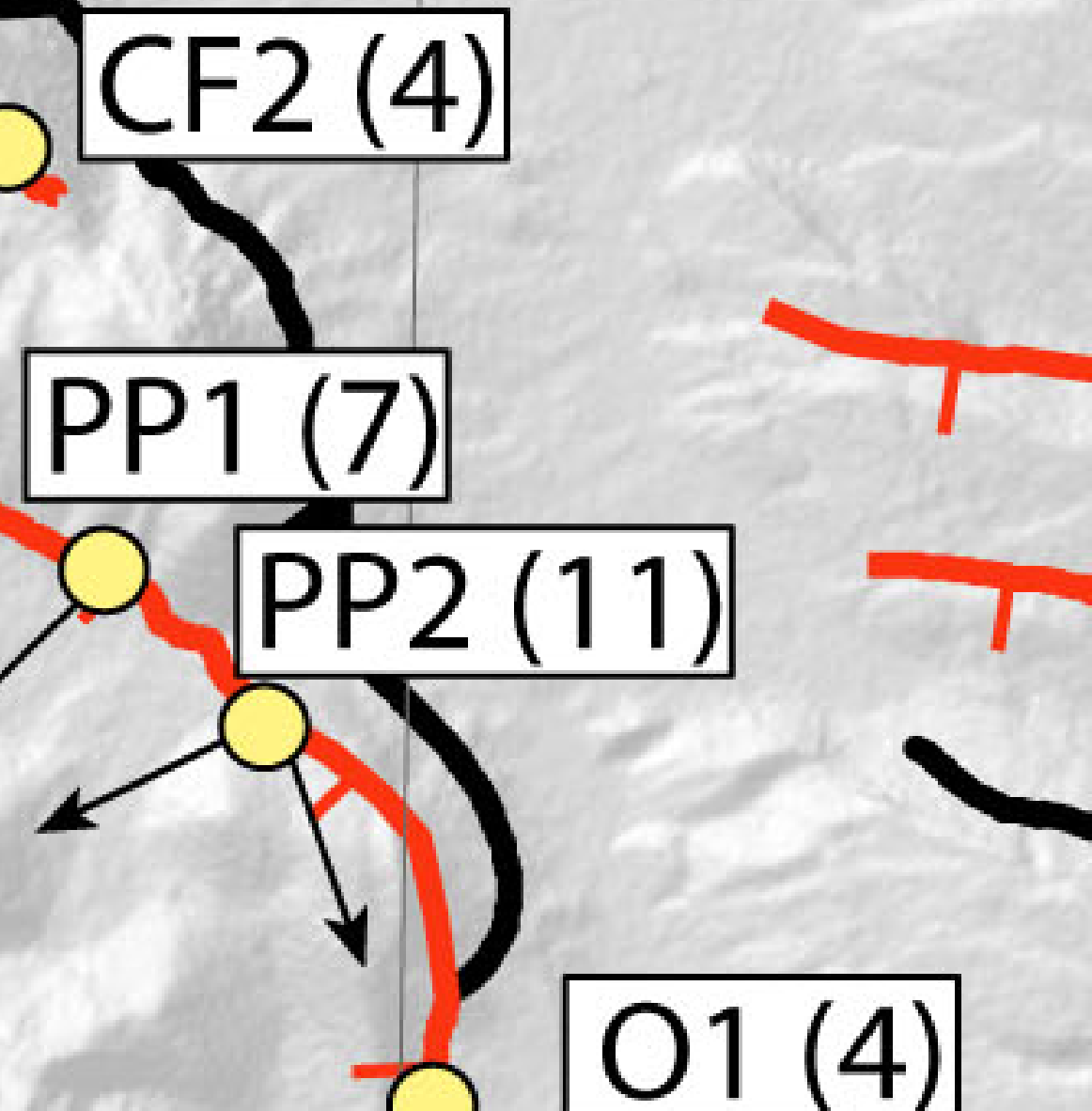

$02(17)$

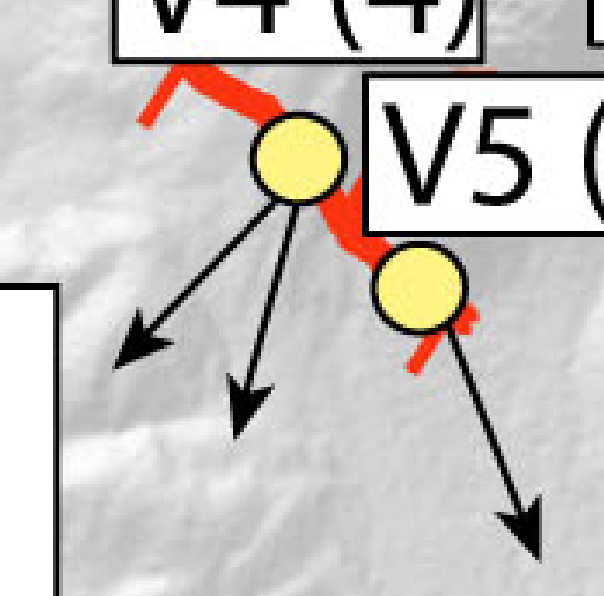

(TRM) Tremonti Fault

$\mathrm{N}$

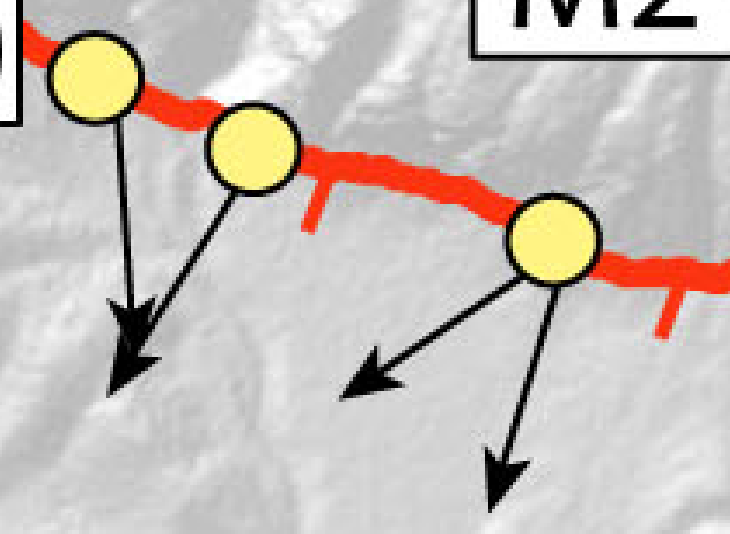

M3 (9) OीO3 (8)

SJ1 (12)

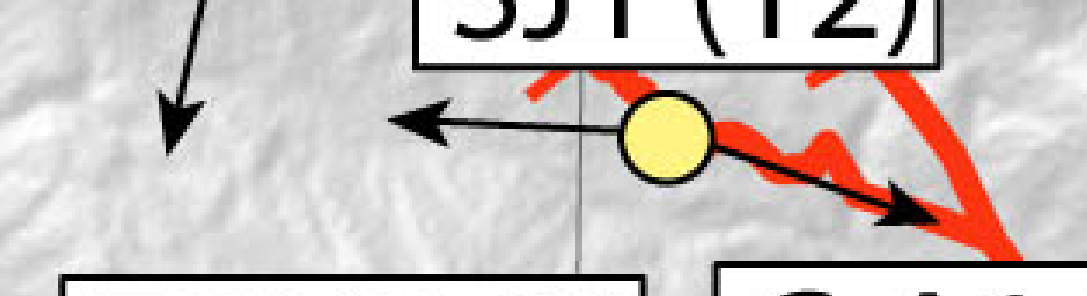

C-A4 (8)

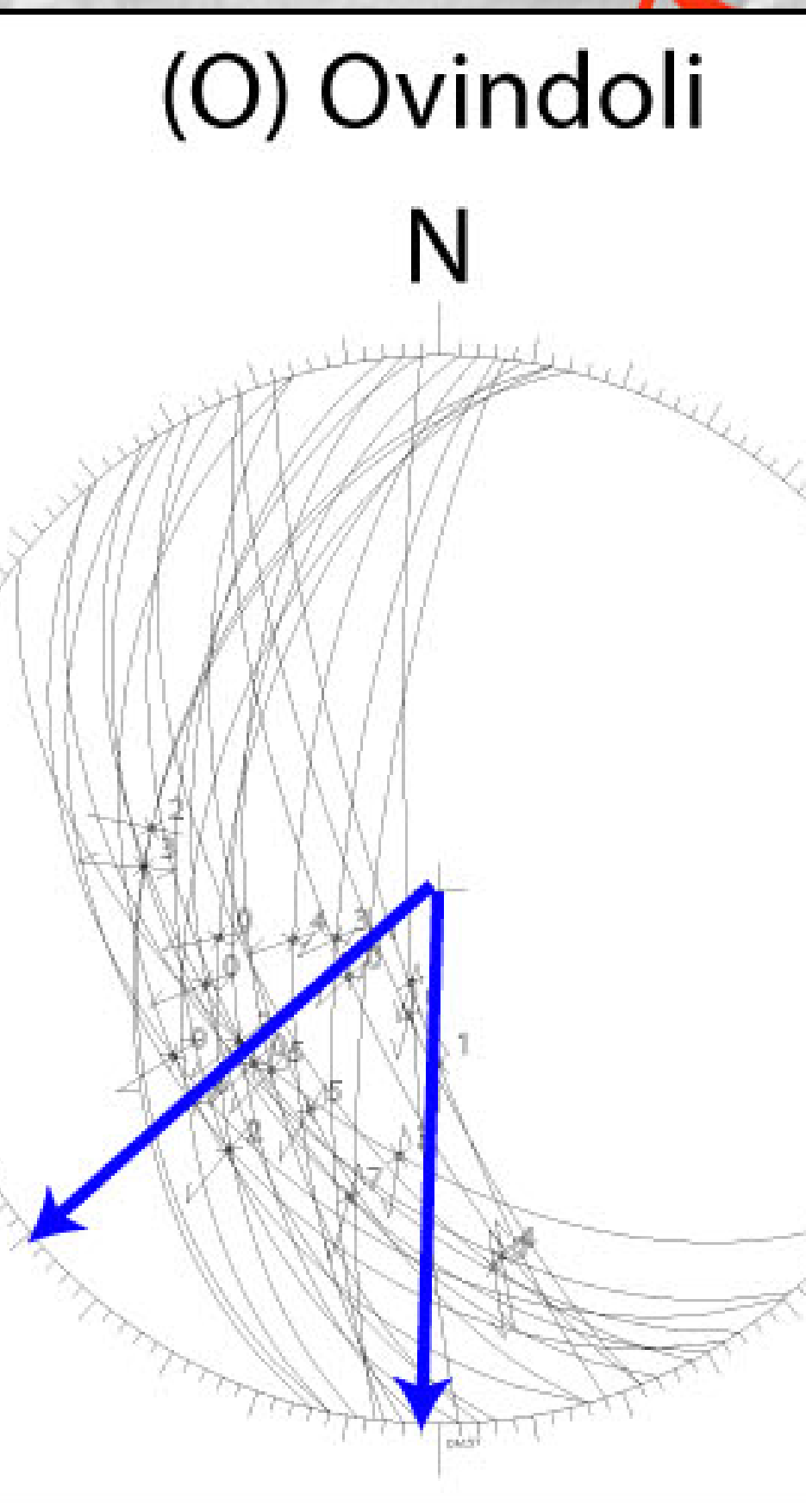

TRM2 (8) C-A1 (9)
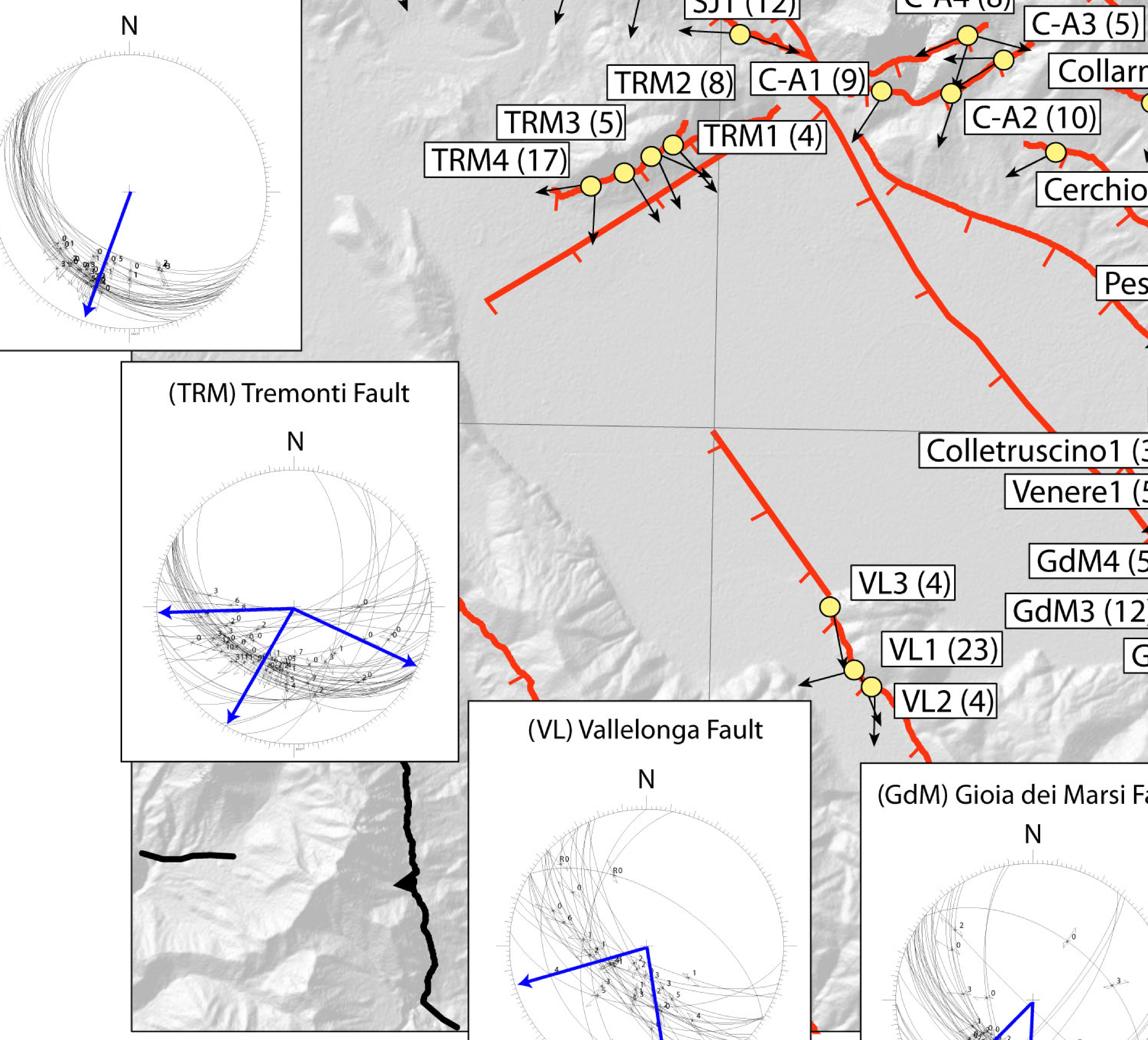

$5 \mathrm{Km}$

$\widehat{\text { Thrust }}$

$\bigcirc \quad$ Measurement Site -

$\perp$

NAME STATION (Number of Measures)

Normal Fault
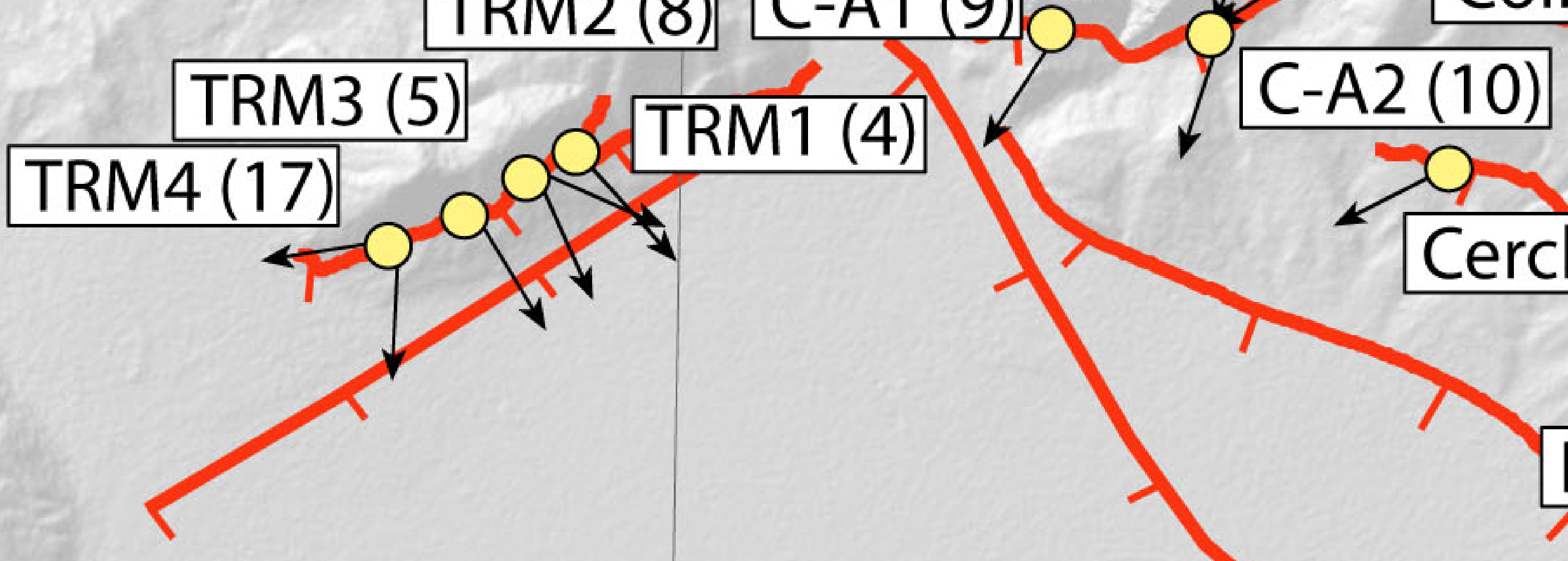

Collar

mele1 (2)
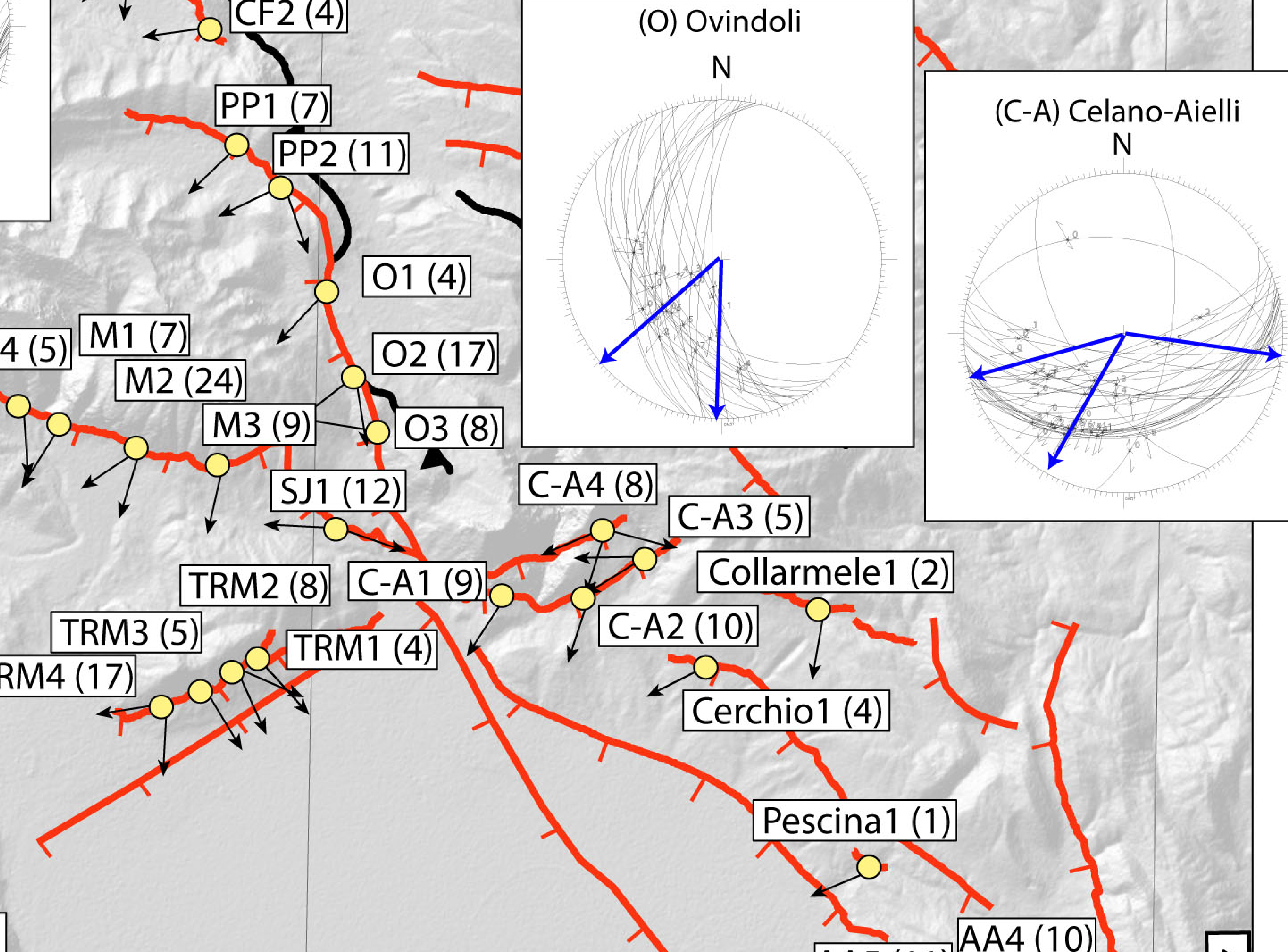

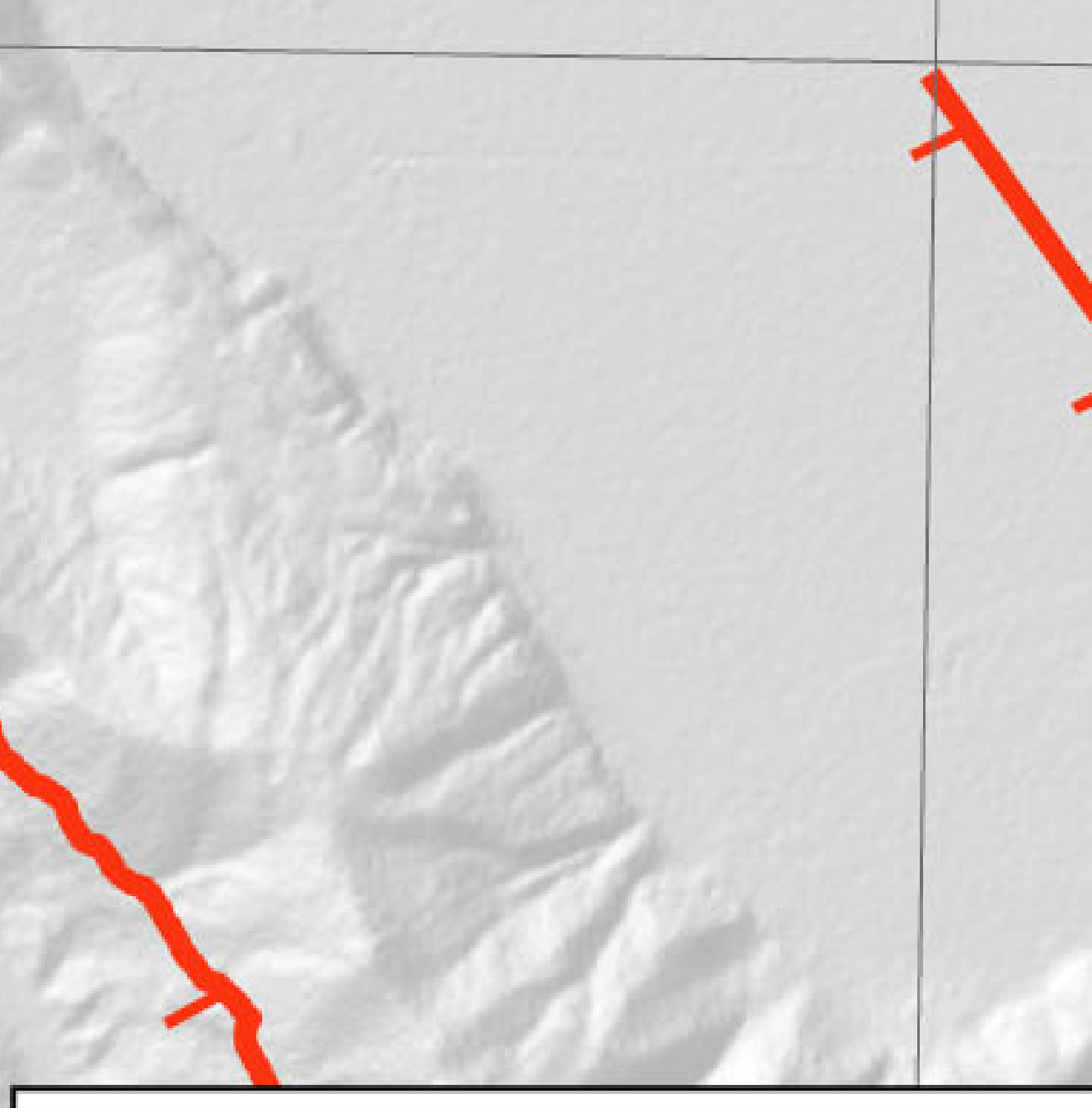

(VL) Vallelonga Fault

$\mathrm{N}$

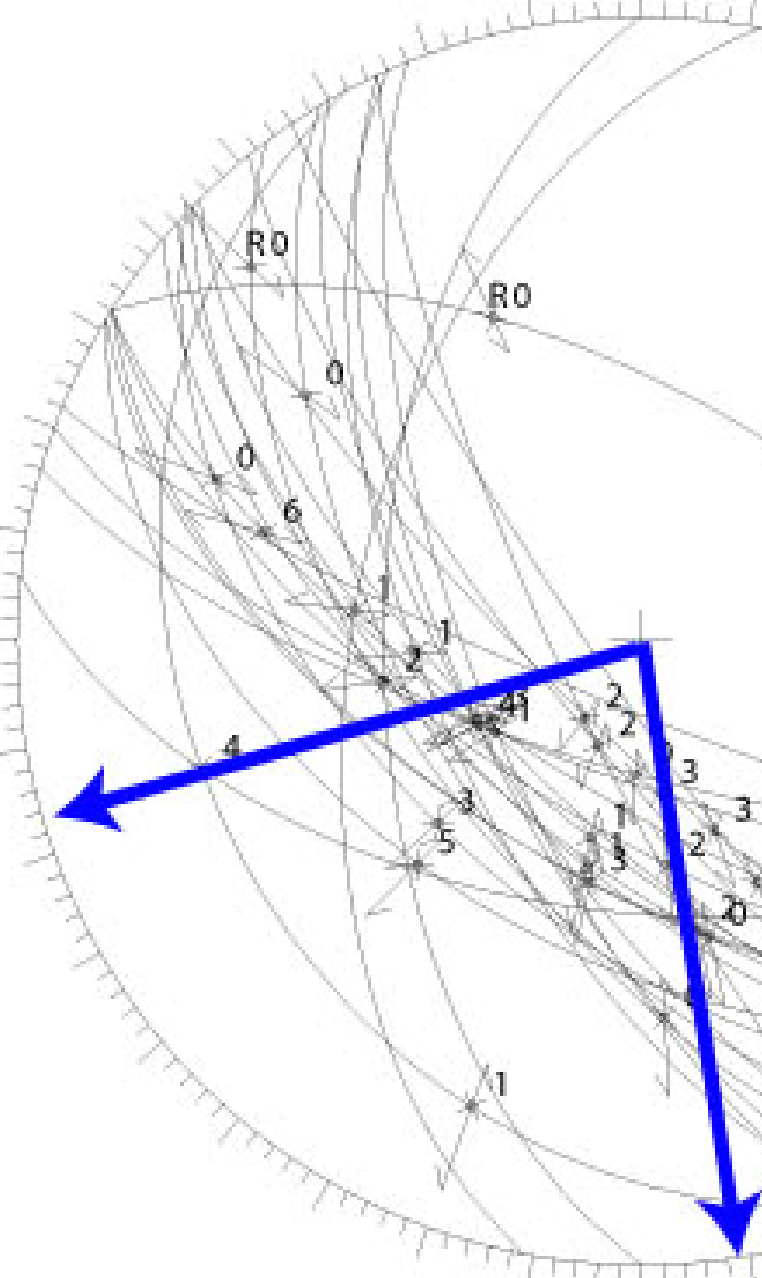

$x+4$

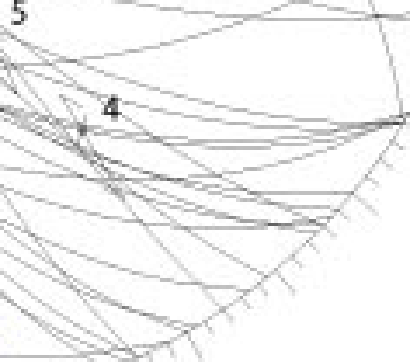

(n)

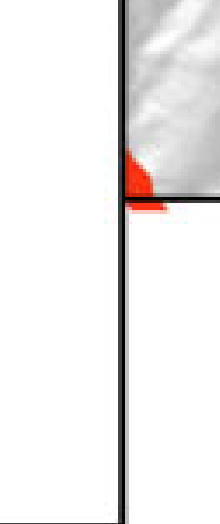

$\left\{\begin{array}{l}\operatorname{VL3}(4) \\ \sqrt{\mathrm{VL2}(4)}\end{array}\right.$

(GdM) Gioia dei Marsi Fault

$\mathrm{N}$

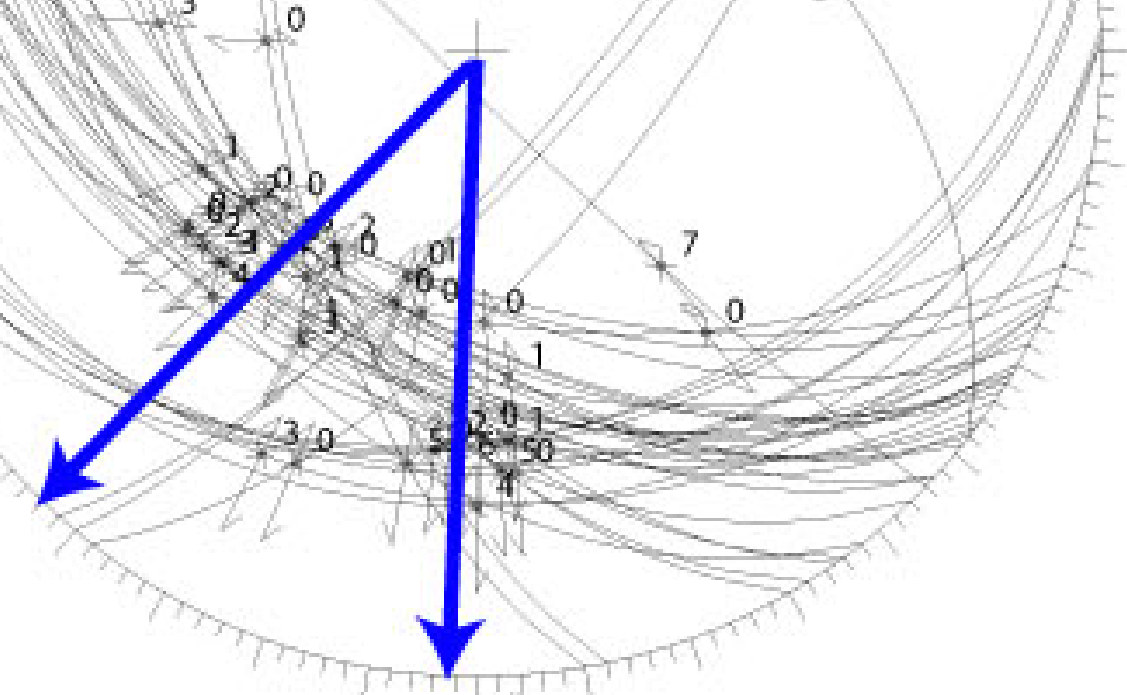

(AA) Aschi Alto Fault

$\mathrm{N}$

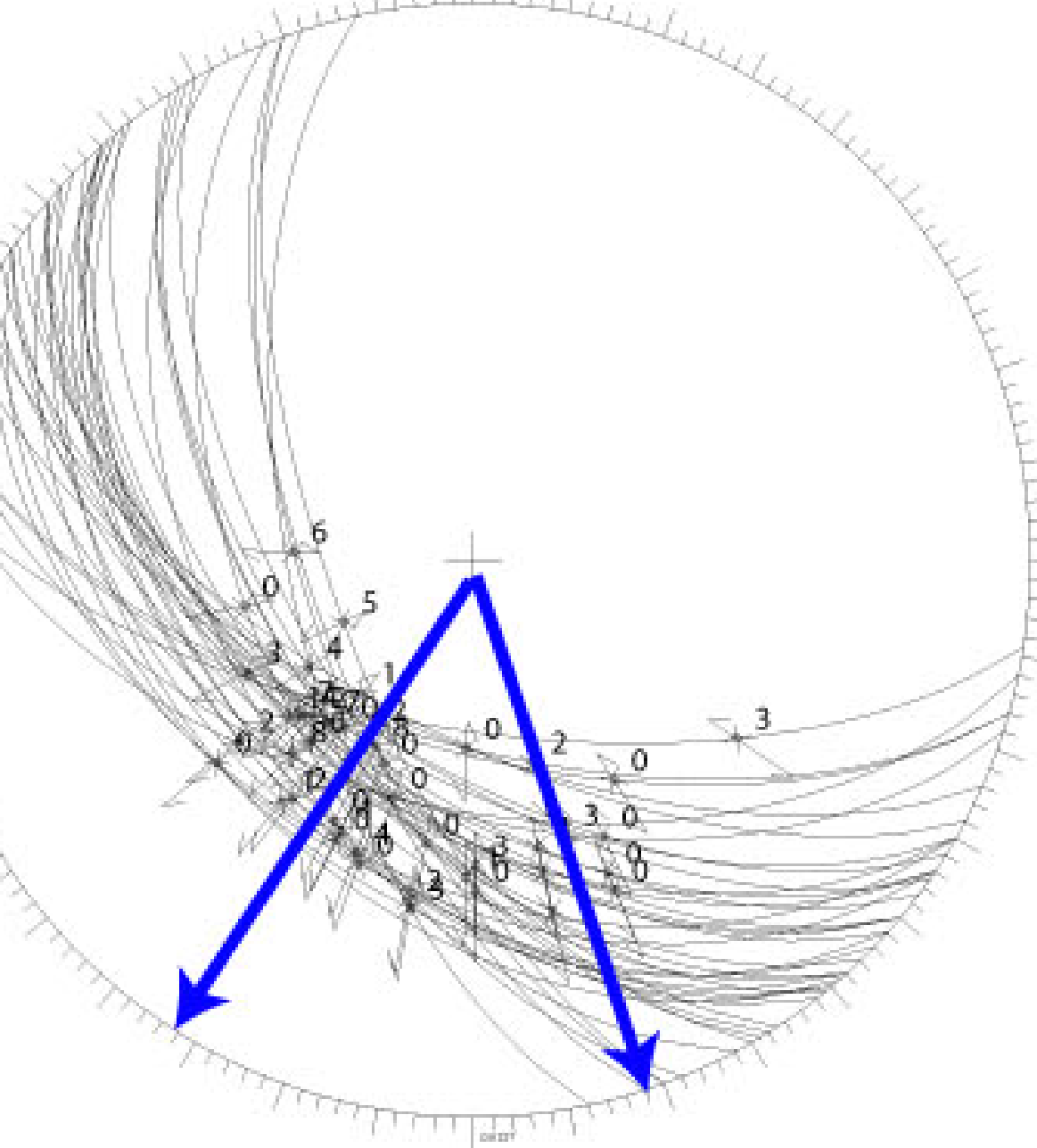

Fault
Slickenlines 
Figure4. 


Figure5. 

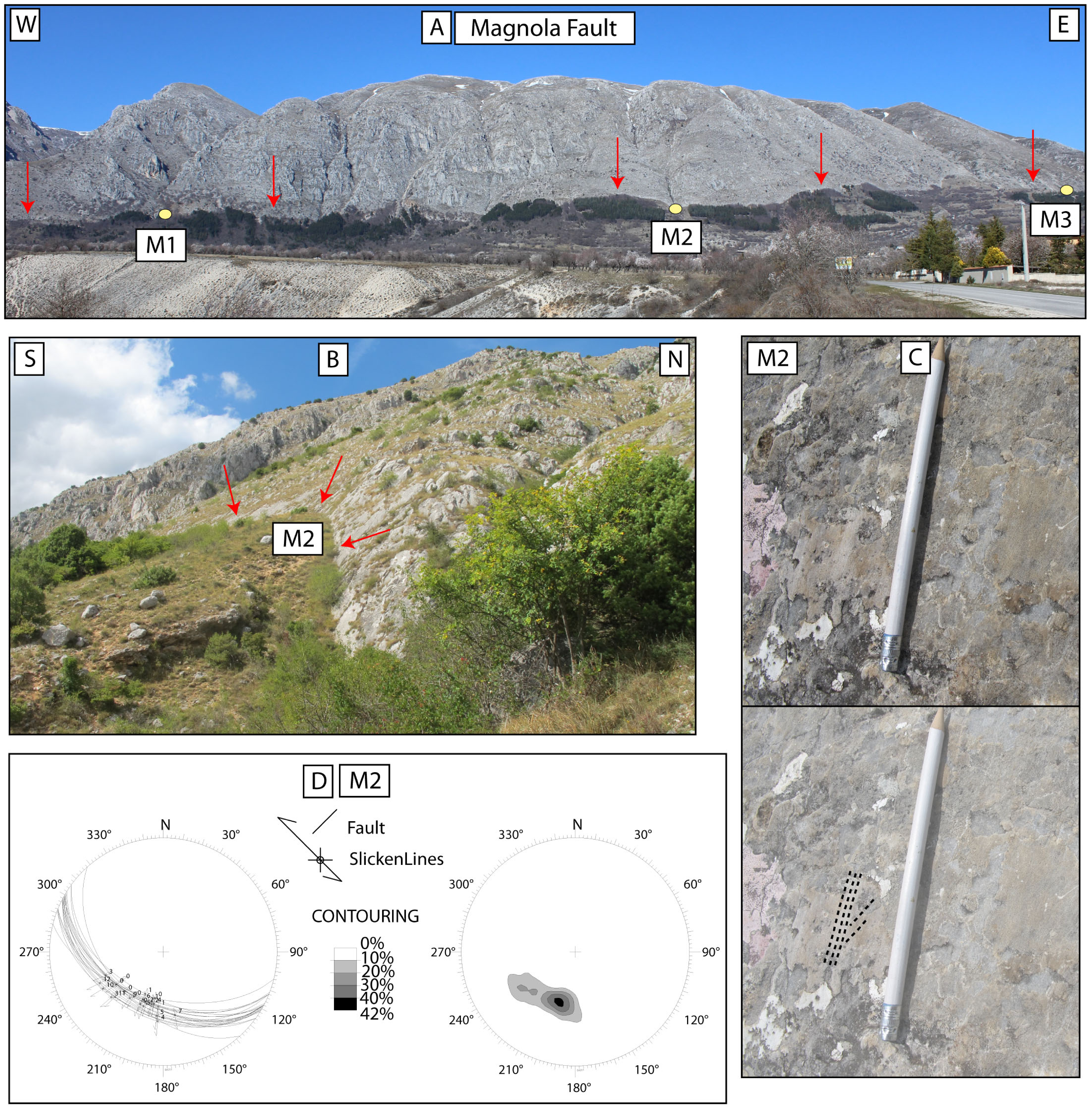
Figure6. 

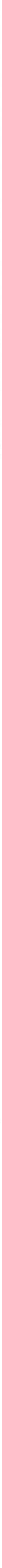
Figure7. 

Figure8. 
Figure9. 


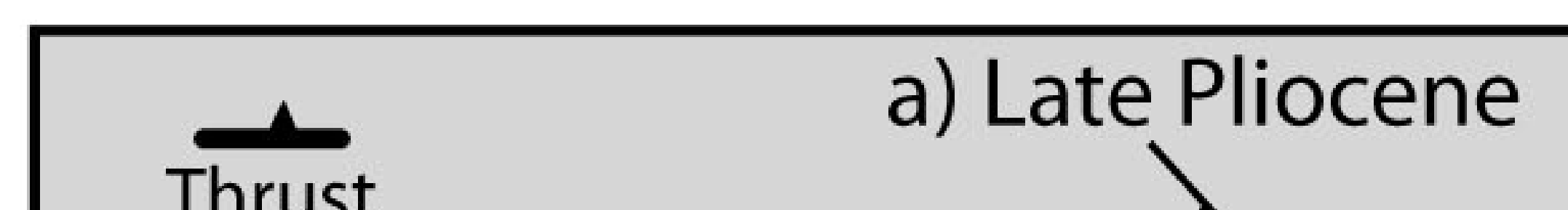

Normal Fault

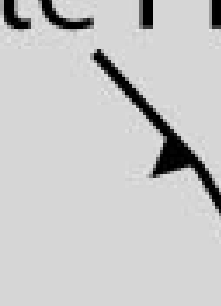

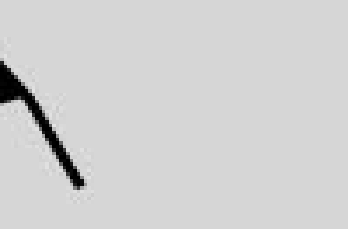

Sediments

Bedrock
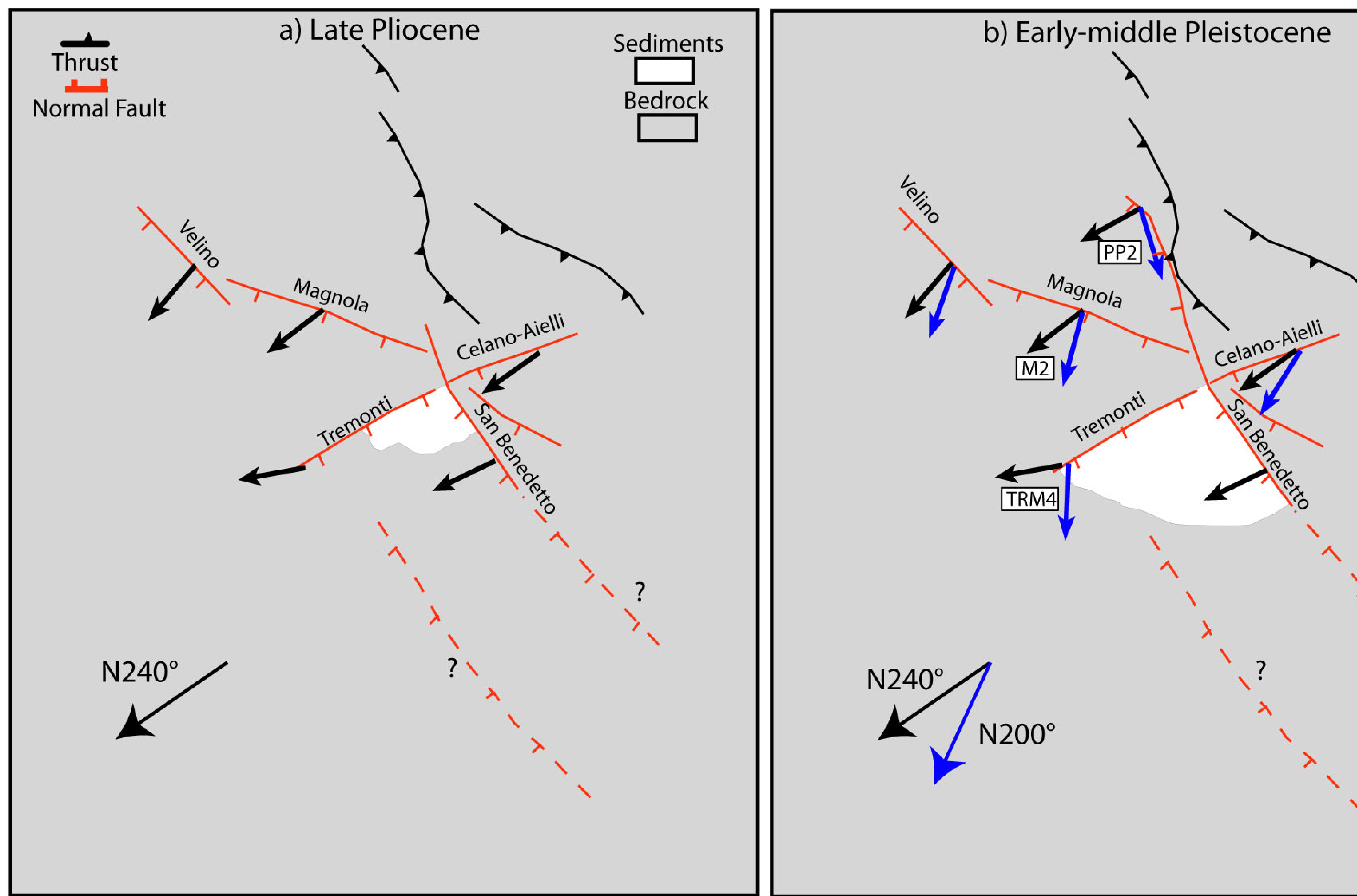

c) Middle-late Pleistocene

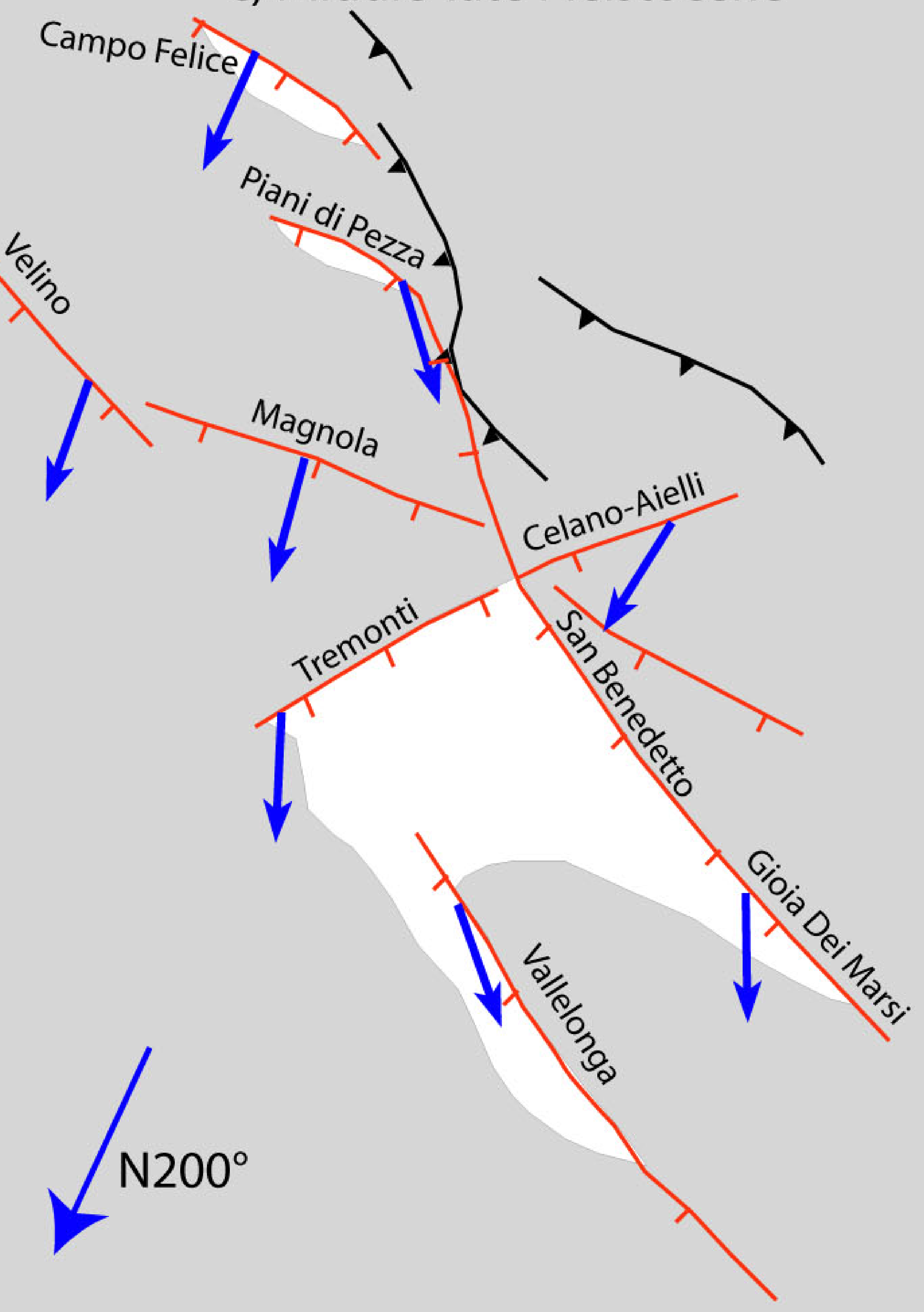

d) Late Pleistocene-Holocene

TRM4

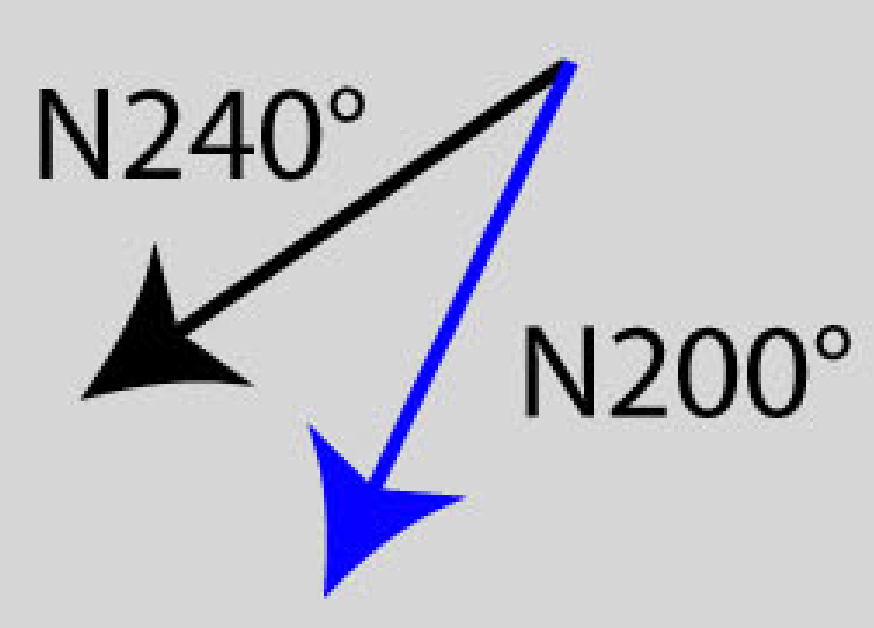

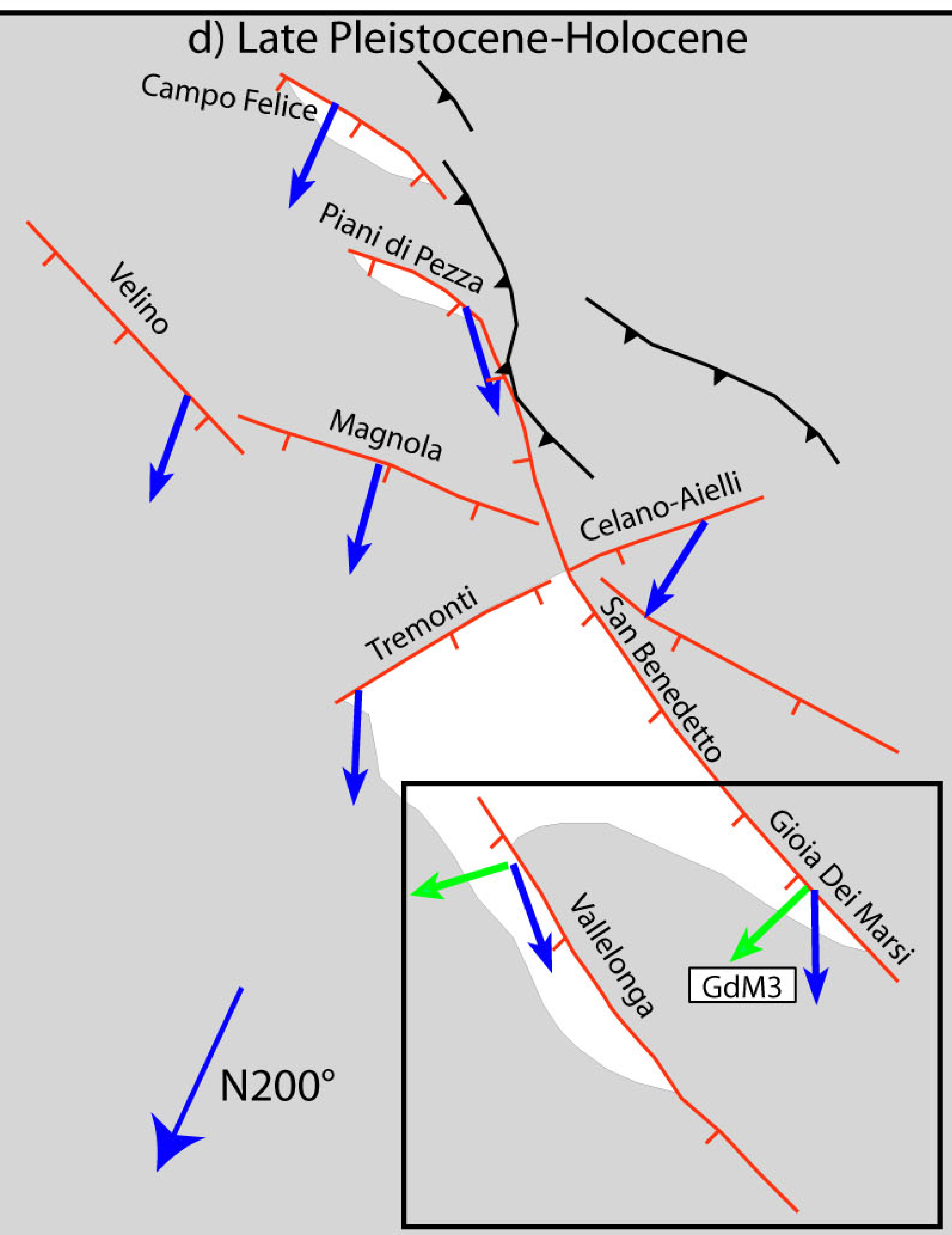
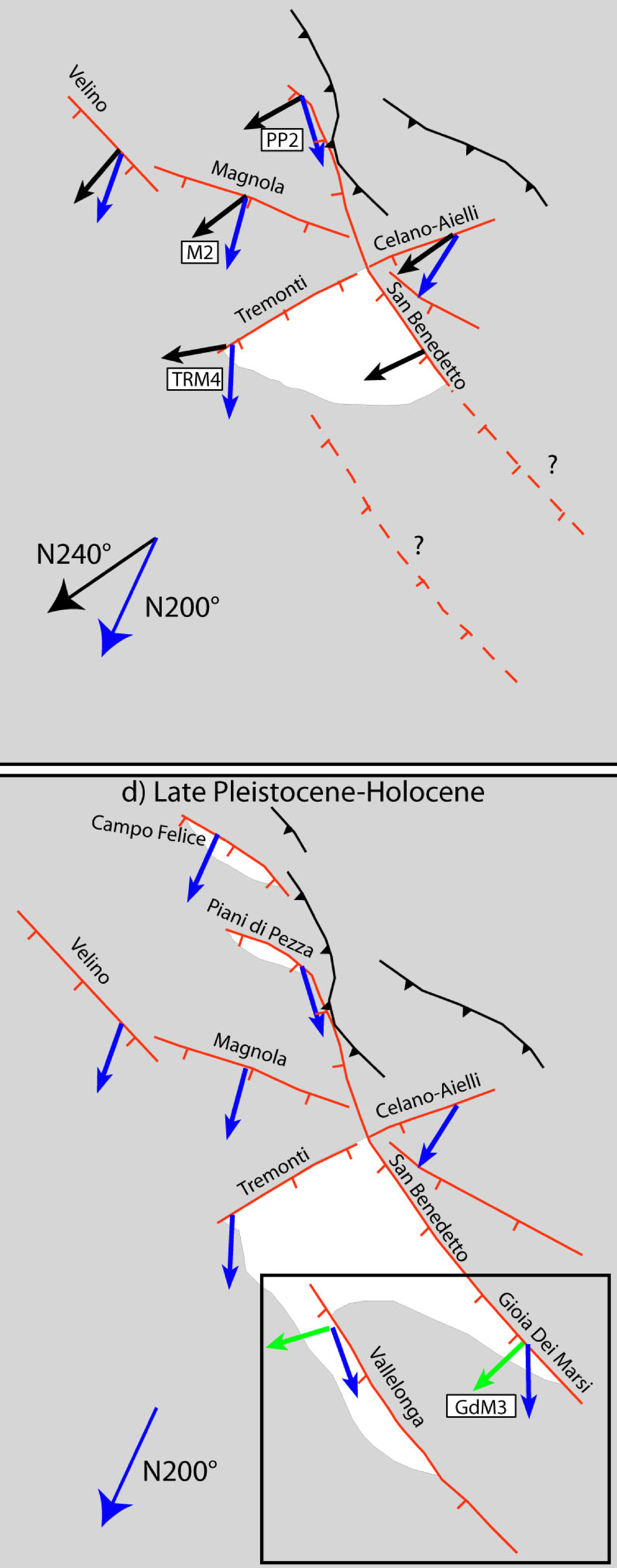
Figure10. 


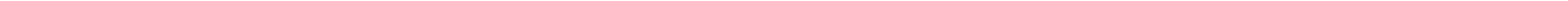


Figure11. 


\section{a) Increasing in vertical displacement}

Sediment thickness (Cavinato et al., 2002)

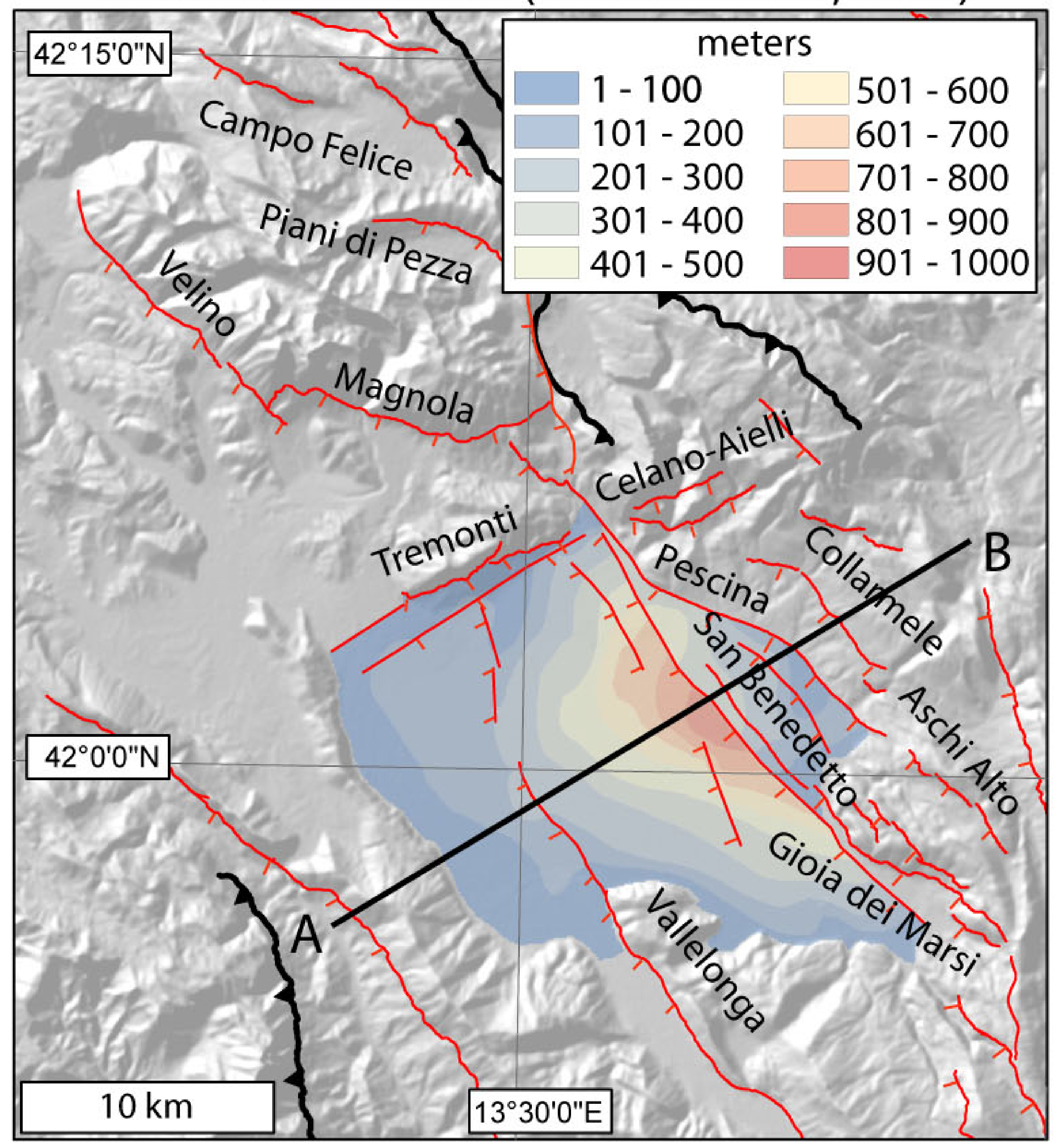

Local Isostasy due to sediment loading

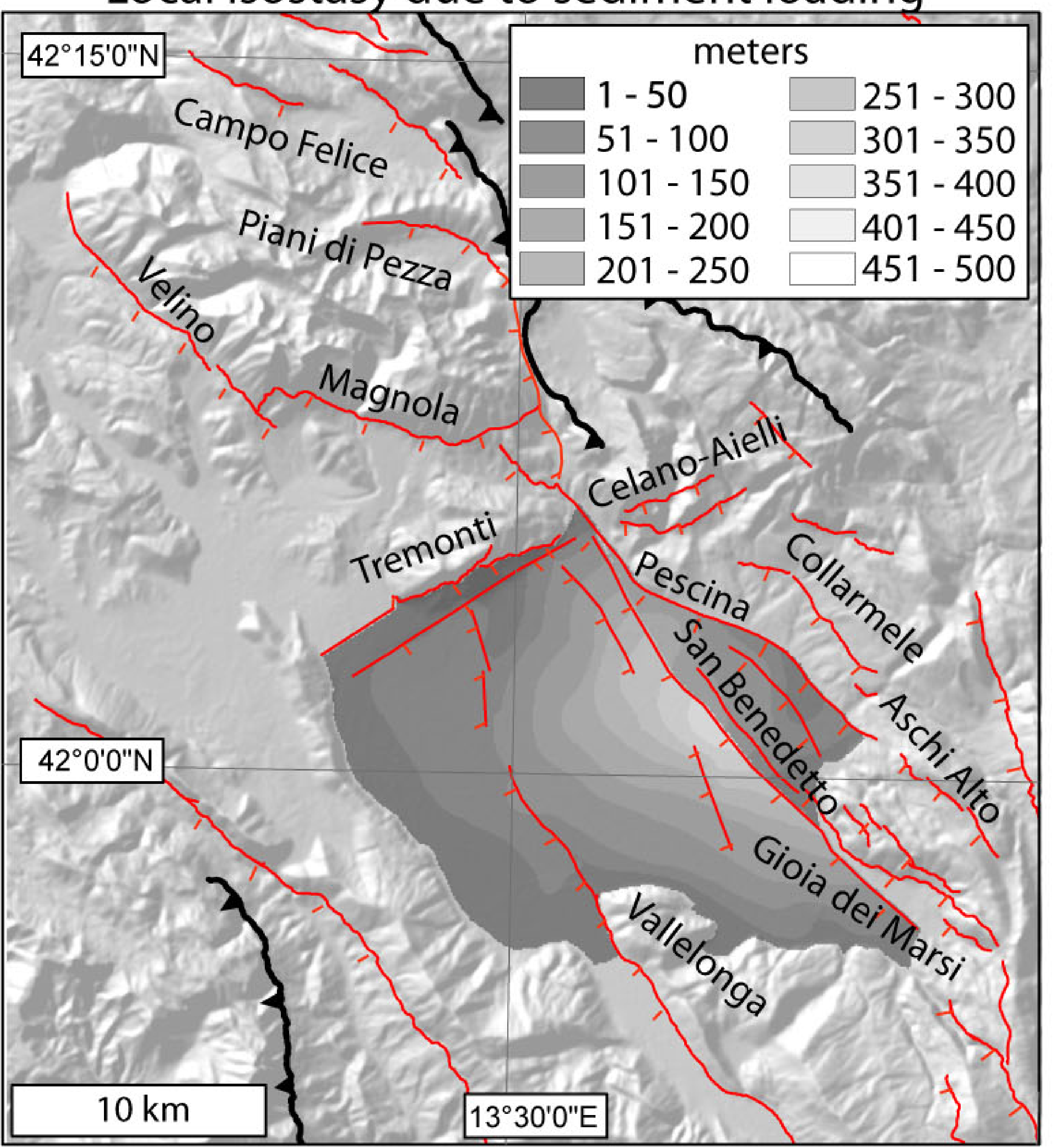

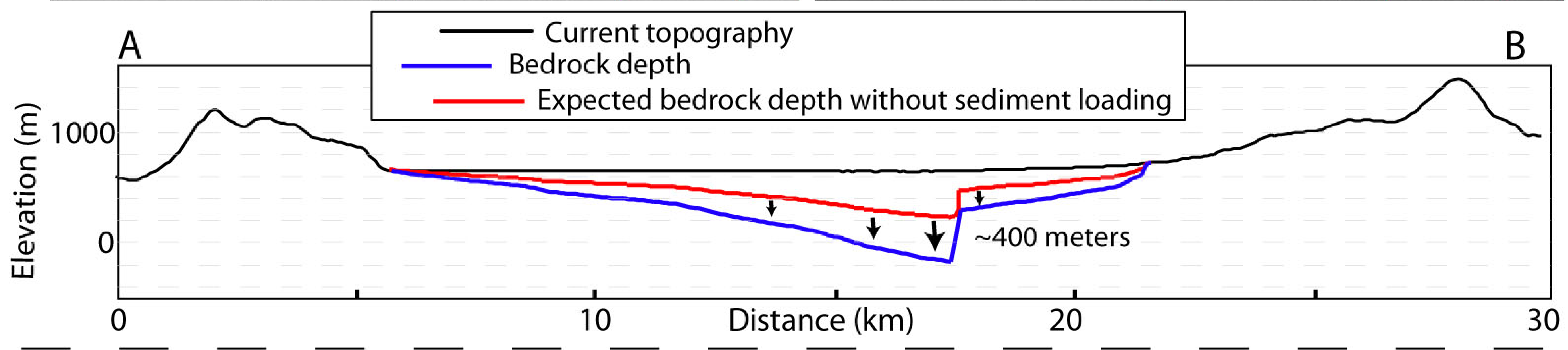

b) Kinematic changing

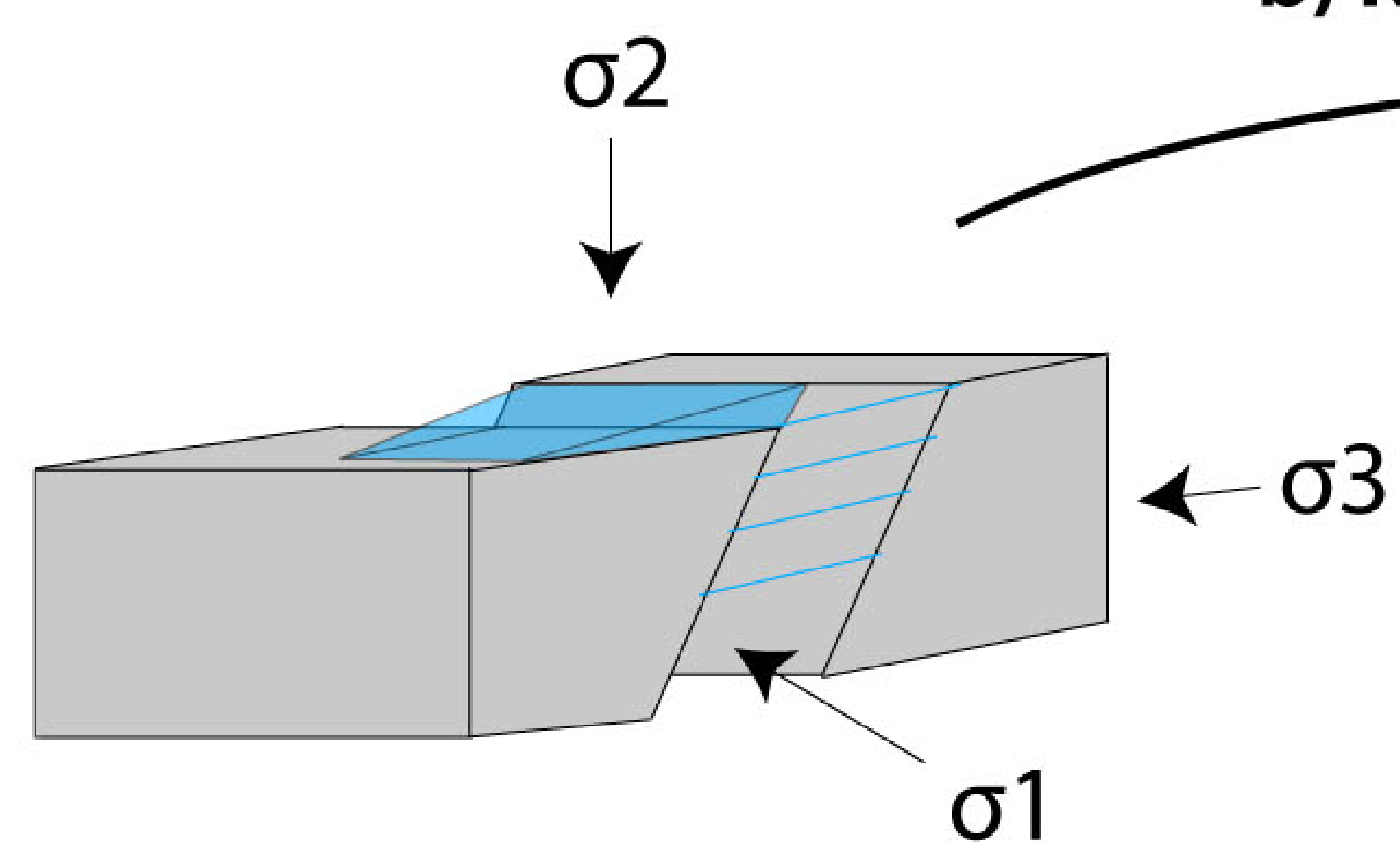

Sequence 3

Sequence 4

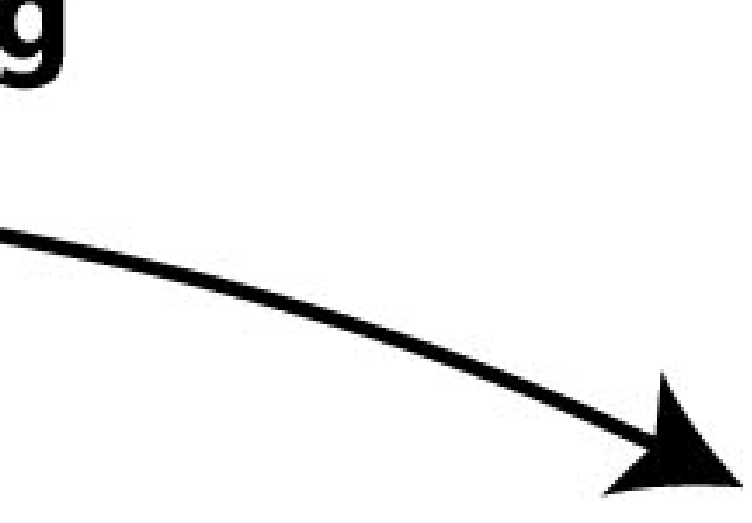

$\sigma 1$

$\sigma 3$

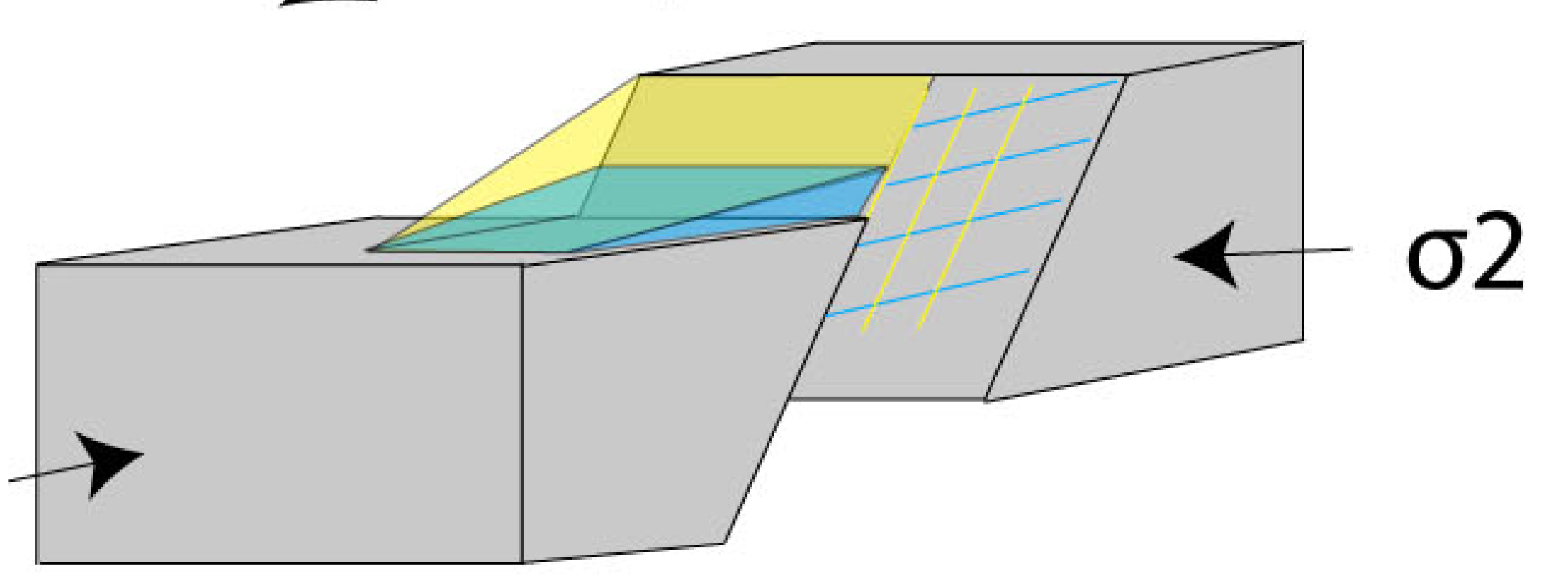

Strike/Oblique-slip Normal dip-slip

stress regime

stress regime

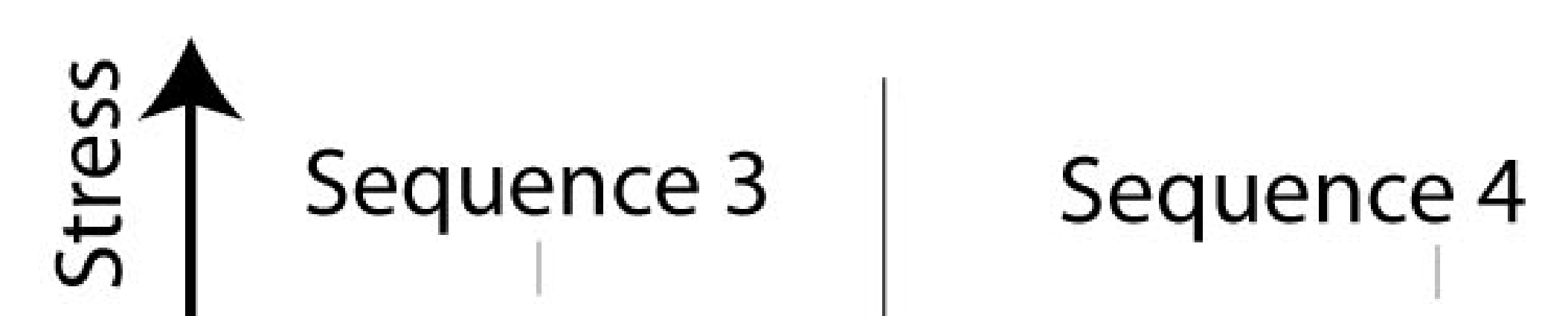

Maximum Horizontal $\sigma$

Minimum Horizontal $\sigma$

Vertical $\sigma$

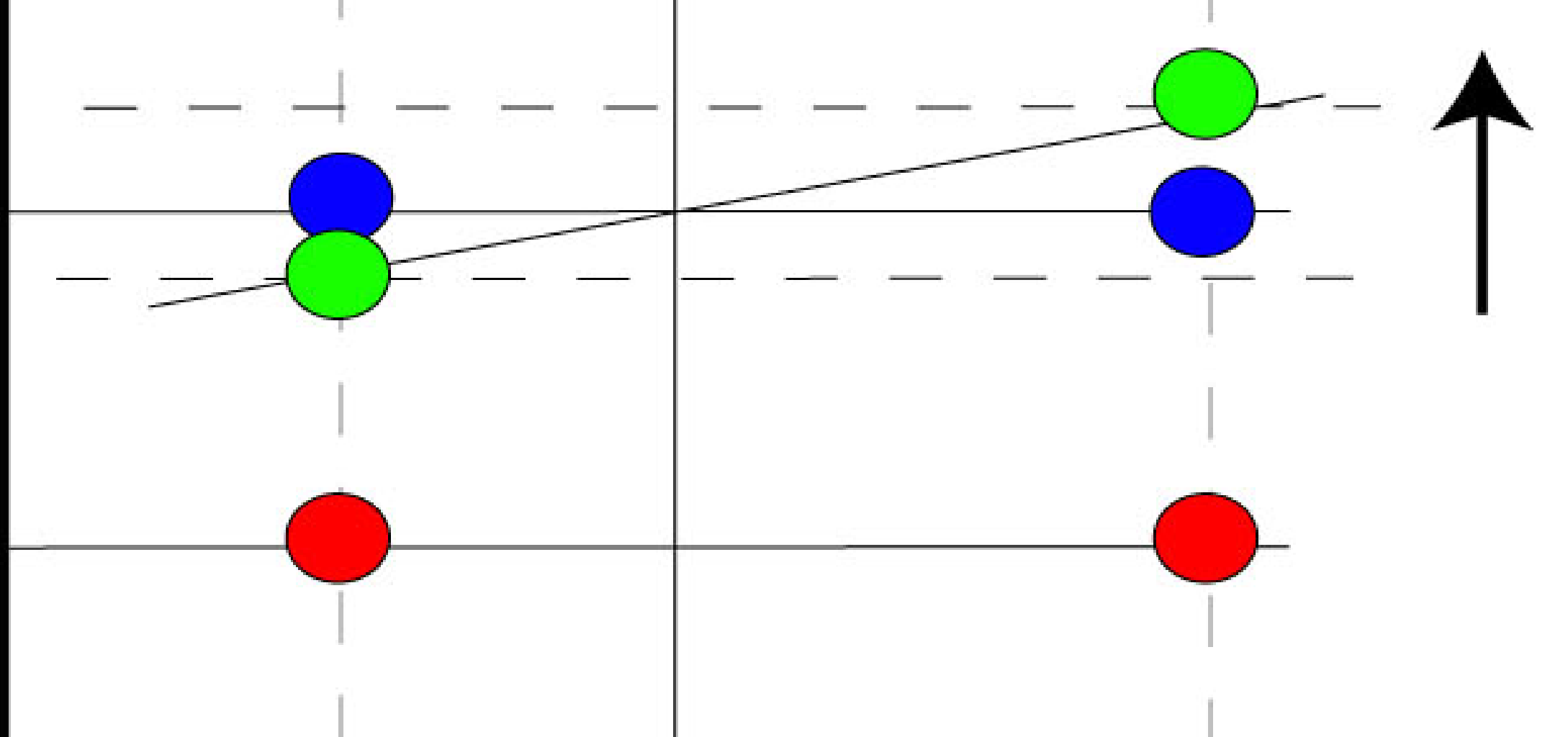

$\sim 15 \mathrm{MPa}$ of total increasing in Vertical $\sigma$

$\uparrow \sim 4 \mathrm{MPa}$ increasing to turn the Vertical $\sigma$ into the maximum $\sigma$ 
Figure12. 
Figure13. 
